ARTICLE

\title{
Splicing the active phases of copper/cobalt-based catalysts achieves high-rate tandem electroreduction of nitrate to ammonia
}

 \\ Sabine Seisel (1) ${ }^{1}$, João R. C. Junqueira ${ }^{1} \&$ Wolfgang Schuhmann (iD) ${ }^{1 \times}$
}

Electrocatalytic recycling of waste nitrate $\left(\mathrm{NO}_{3}{ }^{-}\right)$to valuable ammonia $\left(\mathrm{NH}_{3}\right)$ at ambient conditions is a green and appealing alternative to the Haber-Bosch process. However, the reaction requires multi-step electron and proton transfer, making it a grand challenge to drive high-rate $\mathrm{NH}_{3}$ synthesis in an energy-efficient way. Herein, we present a design concept of tandem catalysts, which involves coupling intermediate phases of different transition metals, existing at low applied overpotentials, as cooperative active sites that enable cascade $\mathrm{NO}_{3}{ }^{-}$to- $\mathrm{NH}_{3}$ conversion, in turn avoiding the generally encountered scaling relations. We implement the concept by electrochemical transformation of $\mathrm{Cu}-\mathrm{Co}$ binary sulfides into potentialdependent core-shell $\mathrm{Cu} / \mathrm{CuO}_{x}$ and $\mathrm{Co} / \mathrm{CoO}$ phases. Electrochemical evaluation, kinetic studies, and in-situ Raman spectra reveal that the inner $\mathrm{Cu} / \mathrm{CuO}$ phases preferentially catalyze $\mathrm{NO}_{3}{ }^{-}$reduction to $\mathrm{NO}_{2}{ }^{-}$, which is rapidly reduced to $\mathrm{NH}_{3}$ at the nearby $\mathrm{Co} / \mathrm{CoO}$ shell. This unique tandem catalyst system leads to a $\mathrm{NO}_{3}{ }^{-}$-to- $\mathrm{NH}_{3}$ Faradaic efficiency of $93.3 \pm 2.1 \%$ in a wide range of $\mathrm{NO}_{3}{ }^{-}$concentrations at $\mathrm{pH} 13$, a high $\mathrm{NH}_{3}$ yield rate of $1.17 \mathrm{mmol} \mathrm{cm}^{-2} \mathrm{~h}^{-1}$ in $0.1 \mathrm{M} \mathrm{NO}_{3}^{-}$at $-0.175 \mathrm{~V}$ vs. RHE, and a half-cell energy efficiency of $\sim 36 \%$, surpassing most previous reports.

\footnotetext{
${ }^{1}$ Analytical Chemistry-Center for Electrochemical Sciences (CES), Faculty of Chemistry and Biochemistry, Ruhr University Bochum, Universitätsstr. 150, 44780 Bochum, Germany. ${ }^{凶}$ email: wolfgang.schuhmann@rub.de
} 
A mmonia $\left(\mathrm{NH}_{3}\right)$ is the critical feedstocks of artificial fertilizers and various chemicals and one of the most promising carbon-free energy carriers ${ }^{1-3}$. Currently, industrial $\mathrm{NH}_{3}$ synthesis heavily relies on the energy and carbon - emission intensive Haber-Bosch (H-B) process $^{4-7}$. Alternatively, electrocatalytic $\mathrm{N}_{2}$-to- $\mathrm{NH}_{3}$ conversion $\left(e \mathrm{~N}_{2}-\mathrm{NH}_{3}\right)$, using water $\left(\mathrm{H}_{2} \mathrm{O}\right)$ as a proton source, has recently attracted significant research interests owing to its mild conditions and high compatibility with renewable electricity ${ }^{6,8-15}$. However, the inherent characters of $\mathrm{N}_{2}$, including high dissociation energy of the $\mathrm{N} \equiv \mathrm{N}$ bond $\left(945 \mathrm{~kJ} \mathrm{~mol}^{-1}\right)$ and low water solubility, make the $e \mathrm{~N}_{2}-\mathrm{NH}_{3}$ work at an insufficient selectivity and two orders of magnitude lower yield rate than that of $\mathrm{H}-\mathrm{B}$ process ${ }^{9-11,16}$. To bridge the gap, the knowledge of the nitrogen cycle brings a renewed attention to the recycling of reactive $\mathrm{N}$-containing species (e.g., $\mathrm{NO}$ and nitrate) to $\mathrm{NH}_{3}{ }^{17-20}$. Among them, the nitrate $\left(\mathrm{NO}_{3}{ }^{-}\right)$ anion is particularly attractive because it exhibits comparatively low dissociation energy of the $\mathrm{N}=\mathrm{O}$ bond $\left(204 \mathrm{~kJ} \mathrm{~mol}^{-1}\right)$ and is widely abundant as pollution in agricultural and industrial wastewaters ${ }^{20-26}$. Furthermore, initial developments of plasma techniques promise to convert air to $\mathrm{NO}_{3}{ }^{-}$with low energy consumption ${ }^{27,28}$. Therefore, using $\mathrm{NO}_{3}{ }^{-}$as the precursor endows $\mathrm{NH}_{3}$ electrosynthesis with sustainable features and opens up an economical route to remedy environmental pollution.

$\mathrm{NO}_{3}{ }^{-}$-to- $\mathrm{NH}_{3}$ conversion in microorganisms is a tandem process; i.e., $\mathrm{NO}_{3}{ }^{-}$reduction to $\mathrm{NO}_{2}{ }^{-}$using nitrate reductase and subsequent $\mathrm{NO}_{2}{ }^{-}$-to- $\mathrm{NH}_{3}$ conversion employing nitrite reductase or nitrogenase, independently ${ }^{29-31}$. This enzyme-based tandem system allows efficient $\mathrm{NH}_{3}$ generation at ambient conditions in nature owing to its specific coordination binding with $\mathrm{NO}_{3}{ }^{-}$and $\mathrm{NO}_{2}{ }^{-}$, respectively ${ }^{29,31,32}$. However, $\mathrm{NO}_{3}{ }^{-}$ typically shows low binding affinity to transition metals in aqueous electrolytes due to its symmetrical $\left(\mathrm{D}_{3 \mathrm{~h}}\right)$ resonant structure and strong hydrogen bonding to $\mathrm{H}_{2} \mathrm{O}^{31,33,34}$. Moreover, the $\mathrm{NO}_{3}{ }^{-}$-to- $\mathrm{NH}_{3}$ pathway involves a complex eight-electrons transfer and multiple intermediates ${ }^{17,35,36}$. As a result, there is a scaling relation between the binding strengths of $\mathrm{NO}_{3}{ }^{-}, \mathrm{NO}_{2}{ }^{-}$ and other oxygen-containing intermediates (e.g., NO) on the transition metal surface ${ }^{37}$. Optimizing the adsorption of one species will typically take the others away from their optima ${ }^{38,39}$, making the simultaneous acceleration of sequential $\mathrm{NO}_{3}{ }^{-}$-to$\mathrm{NO}_{2}{ }^{-}$and $\mathrm{NO}_{2}{ }^{-}$-to- $\mathrm{NH}_{3}$ reactions considerably challenging.

Copper $(\mathrm{Cu})$-based catalysts have been intensively investigated for the $\mathrm{NO}_{3}^{-}$reduction reaction $\left(\mathrm{NO}_{3} \mathrm{RR}\right)$ due to its favorable ability to bind $\mathrm{NO}_{3}{ }^{-}$and catalyze $\mathrm{NO}_{3}{ }^{-}$-to- $\mathrm{NO}_{2}{ }^{-}$ conversion ${ }^{40-43}$. However, pure $\mathrm{Cu}$ catalysts commonly suffer from rapid deactivation because of their strong adsorption of the $\mathrm{NO}_{3} \mathrm{RR}$ intermediates (e.g., $\mathrm{NO}_{2}{ }^{-}$and $\left.\mathrm{NO}\right)^{42-44}$. Substantial efforts have recently been made to alleviate these limitations by regulating the proton- and/or electron-transfer, as well as the binding strengths of partially reduced intermediates adsorbed on $\mathrm{Cu}$ centres. This was performed either by alloying $\mathrm{Cu}$ with noble or other transition metals (e.g., $\mathrm{Pt}, \mathrm{Pd}$ and $\mathrm{Ni})^{40,45-49}$ or through the formation of hybrids with molecular solids or metal oxides (e.g., $\left.\mathrm{Cu}_{2} \mathrm{O}\right)^{44,50,51}$. These strategies have increased the Faradaic efficiency (FE) of $\mathrm{NH}_{3}$ to an impressive $70-100 \%$ and the $\mathrm{NH}_{3}$ yield rate $\left(\mathrm{Y}_{\mathrm{NH} 3}\right)$ to a level of $30-200 \mu \mathrm{mol} \mathrm{cm}{ }^{-2} \mathrm{~h}^{-1} 44,45,51$. However, restricted by the scaling relations, these advances require highly concentrated $\mathrm{NO}_{3}^{-}$(e.g., $1 \mathrm{M}$ ) and/or relatively high overpotentials $(<-0.4 \mathrm{~V}$ vs. RHE) to balance the rates of $\mathrm{NO}_{3}{ }^{-}$-to- $\mathrm{NO}_{2}{ }^{-}$and $\mathrm{NO}_{2}{ }^{-}$-to- $\mathrm{NH}_{3}$ reactions, resulting in an increased energy consumption ${ }^{44,45,51}$. To compete with the $\mathrm{H}-\mathrm{B}$ process, further progress on $\mathrm{Y}_{\mathrm{NH} 3}\left(>1 \mathrm{mmol} \mathrm{cm}{ }^{-2} \mathrm{~h}^{-1}\right)^{52}$ and on decreasing energy consumption are highly desirable.

Energy-efficient $\mathrm{NO}_{3} \mathrm{RR}$ points to low operating overpotentials (e.g., $>-0.2 \mathrm{~V}$ vs. $\mathrm{RHE}$ ), at which transition metal (e.g., $\mathrm{Cu}$ and
Co)-based catalysts often suffer from potential-dependent phase evolution, leading to the coexistence of multiple phases, such as metallic, oxide and hydroxide phases ${ }^{53-56}$. In situ monitoring of the phase evolution of transition metals during the $\mathrm{NO}_{3} \mathrm{RR}$, while correlating these intermediate phases with specific catalytic steps $^{53,54,57,58}$, may not only guide the rational design of selective catalysts for $\mathrm{NH}_{3}$ but also provide insight into the $\mathrm{NO}_{3} \mathrm{RR}$. Inspired by the tandem $\mathrm{NO}_{3}{ }^{-}$-to- $\mathrm{NH}_{3}$ conversion in nature ${ }^{29}$, we sought, therefore, to circumvent the scaling relations by combining two or more cooperative intermediate phases exhibiting complementary catalytic selectivity into one tandem system, intending to achieve $\mathrm{NH}_{3}$ synthesis at low overpotentials. Importantly, it has been clearly demonstrated that the reaction rate and selectivity of a tandem catalyst system, linked to the transport of key intermediates, could be optimized by judiciously tuning the proximity, hierarchy and content ratio of multiple active phases ${ }^{39,59-62}$. Accordingly, the $\mathrm{Y}_{\mathrm{NH} 3}$ could be further improved, however, to the best of our knowledge, tandem catalysts based on earth-abundant elements have never been reported for electrocatalytic consecutive $\mathrm{NO}_{3}{ }^{-}$-to- $\mathrm{NH}_{3}$ conversion.

In this work, we introduce a facile electrochemically driven phase-separation strategy for a tandem catalyst design, which, different from previous approaches based on sequential assembling or deposition ${ }^{60,61}$, enables the in situ formation of multiple active intermediate phases and rich phase interfaces for rapid spillover and transport of reaction intermediates. As a proof-ofconcept, we implemented this catalyst synthesis strategy by the electrochemical transformation of pre-synthesized $\mathrm{Cu}-\mathrm{Co}$ binary metal sulfides into core-shell $\mathrm{Cu} / \mathrm{CuO}$ and $\mathrm{Co} / \mathrm{CoO}$ phases on $\mathrm{Cu}$ foil. The employment of Co-based phases as a sub -component of the tandem catalysts was inspired by the previously reported high selectivity of Co-based materials and complexes for $\mathrm{NH}_{3}$ generation during the $\mathrm{NO}_{3} \mathrm{RR}$ and the specific $\mathrm{NO}_{2}{ }^{-}$-to- $\mathrm{NH}_{3}$ conversion ${ }^{63,64}$. Our electrocatalytic tests, kinetic studies, in situ scanning electrochemical microscopy (SECM) and in situ Raman spectra reveal that at low overpotentials, the inner $\mathrm{Cu} / \mathrm{CuO}_{\mathrm{x}}$ phases preferentially catalyze $\mathrm{NO}_{3}{ }^{-}$reduction to $\mathrm{NO}_{2}{ }^{-}$, while the outer-layer $\mathrm{Co} / \mathrm{CoO}$ phases selectively catalyze $\mathrm{NO}_{2}{ }^{-}$reduction to $\mathrm{NH}_{3}$, both of which can be combined for rapid "working-in-tandem" $\mathrm{NH}_{3}$ synthesis. As a result, we report $\mathrm{NO}_{3}{ }^{-}$-to- $\mathrm{NH}_{3}$ conversion with a $\mathrm{FE}$ of $93.3 \pm 2.1 \%$ in a wide range of $\mathrm{NO}_{3}{ }^{-}$concentrations at $-0.175 \mathrm{~V}$ vs. RHE, a high $\mathrm{NH}_{3}$ yield rate of $1.17 \mathrm{mmol} \mathrm{cm}^{-2} \mathrm{~h}^{-1}$ in $0.1 \mathrm{M}$ $\mathrm{NO}_{3}{ }^{-}$at $\mathrm{pH} 13$ and a half-cell energy efficiency of $\sim 36 \%$, which surpass most prevreports.

\section{Results}

Catalyst design and characterization. The synthesis of $\mathrm{Cu} / \mathrm{Co}-$ based tandem catalysts is schematically illustrated in Fig. 1a. A nanorod array of metal-organic frameworks (MOFs) was first grown on $\mathrm{Cu}$ foil by optimizing the molar ratio of 2-methylimidazole and $\mathrm{Co}^{2+}$ to 20: 1 (hereafter named as ZIFCo-R/Cu; Fig. $1 \mathrm{~b}$ and Supplementary Fig. S1). The ZIF-Co-R/Cu was converted into $\mathrm{Cu}-\mathrm{Co}$ binary metal sulfides following a previously reported electrochemically conversion of MOF (ECMOF) strategy ${ }^{65-67}$. Upon adding $0.05 \mathrm{M} \mathrm{Na}_{2} \mathrm{HPO}_{4}$ as structuretuning agents, the nanorod contour of $\mathrm{ZIF}-\mathrm{Co}-\mathrm{R}$ could be retained during the EC-MOF (Fig. 1c), which was otherwise changed into super-thin nanosheets (Supplementary Fig. S2). We denoted the $\mathrm{PO}_{4}{ }^{3-}$-modified $\mathrm{Cu}$-Co binary metal sulfides as CuCoSP_no and their products after further electrochemical redox activation as CuCoSP. This unique nanorod array configuration of $\mathrm{CuCoSP}$ can provide a more efficient pathway for mass and charge transport during the $\mathrm{NO}_{3} \mathrm{RR}$, contributing to the best performance of CuCoSP for $\mathrm{NO}_{3} \mathrm{RR}$ as discussed below. 
a
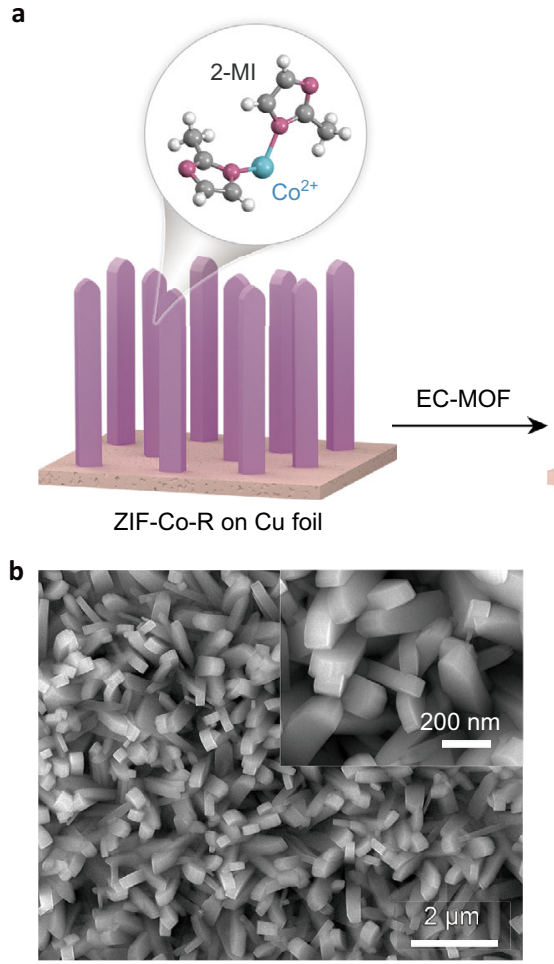

e

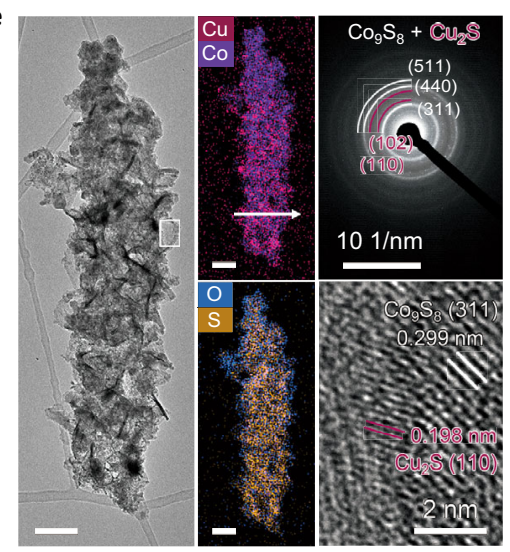

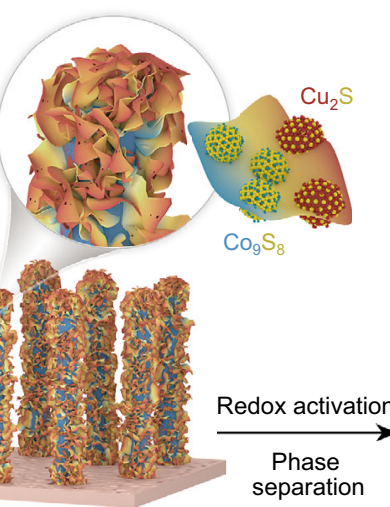

CuCoSP_no
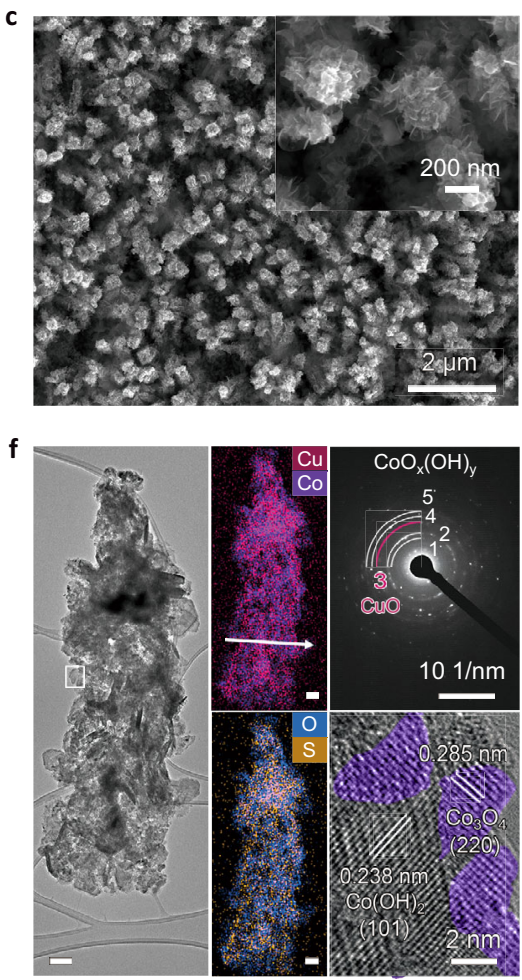

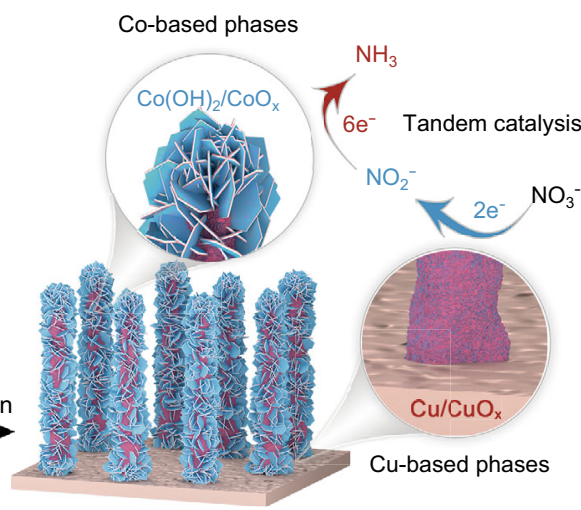

CuCosP
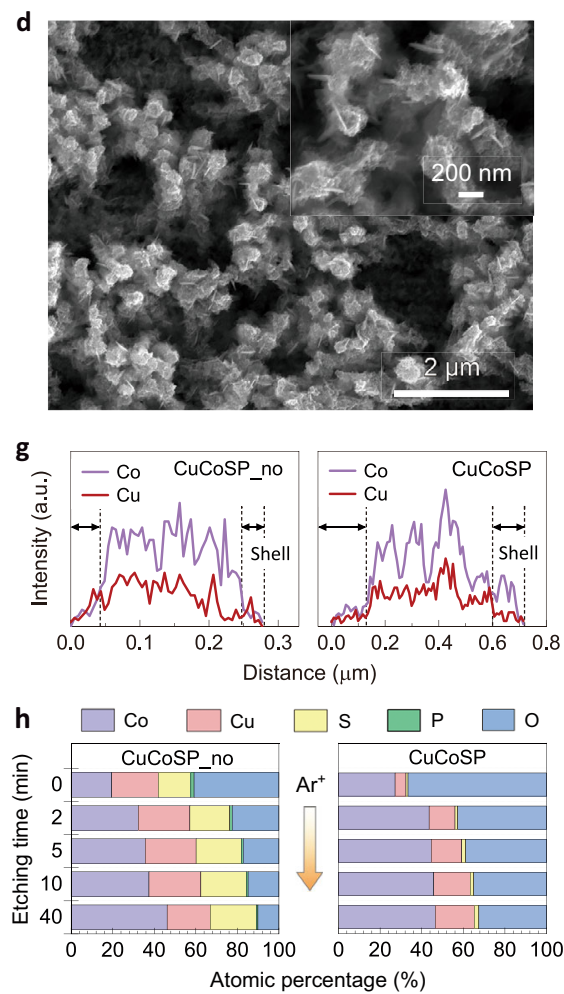

Fig. 1 Structural characterizations of catalysts. a Schematic illustration of the preparation of a Cu/Co-based binary 'tandem catalyst'. SEM images of the ZIF-Co-R precursor (b), CuCoSP_no (c) and CuCoSP (d) on the Cu foil substrate. The inset figures are the SEM images at higher magnification. e, $\mathbf{f}$ Typical TEM image, EDX mappings, SAED patterns and HR-TEM image of CuCoSP_no (e) and CuCoSP (f). Unlabelled scale bars are $100 \mathrm{~nm}$. The SAED patterns in (f) show the presence of $\mathrm{CuO}$ phases and $\mathrm{Co}$-based oxides/hydroxides $\left(\mathrm{CoO}_{x}(\mathrm{OH})_{y}\right)$, where $1=\mathrm{Co}(\mathrm{OH})_{2}(100), 2=\mathrm{Co}(\mathrm{OH})_{2}(101), 3=\mathrm{CuO}(2 \mathrm{O} \overline{2}), 4=$ $\mathrm{CoOOH}(211)$ and $5=\mathrm{CoO}(220)$. The purple colours of the HR-TEM image in (f) are marked to guide the eye and correspond to the $\mathrm{CO}_{3} \mathrm{O}_{4}$ nanocrystals. $\mathbf{g}$ EDX line-scan of a selected area marked by the white arrows in (e) and (f). $\mathbf{h}$ XPS-determined atomic percentage-depth profile of CuCoSP_no and $\mathrm{CuCoSP}$ as a function of $\mathrm{Ar}^{+}$etching time. 2-MI 2-methylimidazole; EC-MOF electrochemically conversion of metal-organic frameworks.

Low-resolution transmission electron microscopy (TEM) and high-resolution scanning electron microscopy (HR-SEM) images reveal that a curly nanosheet-assembled shell wraps the nanorod skeleton of CuCoSP_no (Fig. 1c, e and Supplementary Fig. S3a). The corresponding EDX mapping shows strong $\mathrm{Co}, \mathrm{Cu}$ and $\mathrm{S}$ signals well-distributed in the whole nanorod and a weak signal of $\mathrm{O}$ due to surface oxidation. Remarkably, $\mathrm{Cu}$ is also spread over the nanorod, indicating that the $\mathrm{Cu}$ comprised in CuCoSP_no is from the dissolution of $\mathrm{Cu}$ foil followed by redeposition and inward diffusion of the released $\mathrm{Cu}$ ions during the EC-MOF. The enrichment of $\mathrm{Cu}$ on the CuCoSP_no surface is supported by the EDX-linear scan (Fig. $1 \mathrm{~g}$ and Supplementary Fig. S3). Moreover, HR-TEM images, coupled with selected area electron diffraction (SAED), reveal that the curly nanosheets and skeleton of
CuCoSP_no are mainly composed of $\sim 3-5 \mathrm{~nm} \mathrm{Co} 9 \mathrm{~S}_{8}$ and $\mathrm{Cu}_{2} \mathrm{~S}$ nanocrystals, which are not detectable by X-ray diffraction (XRD) (Supplementary Fig. S4d) ${ }^{59,66}$.

After the electrochemical activation, the obtained CuCoSP preserves the contour of CuCoSP_no, except for the in situ formation of a hexagon-shaped nanosheet-assembled shell (Fig. 1d, f and Supplementary Fig. S5a). Compared to CuCoSP_no, the CuCoSP possesses more complex SAED patterns corresponding to multiple mixed phases (Fig. 1f), which include $\mathrm{Co}(\mathrm{OH})_{2}, \mathrm{CoOOH}, \mathrm{CoO}$ and $\mathrm{CuO}$ EDX mappings and linear EDX scans (Fig. If and Supplementary Fig. S5f) show weaker $\mathrm{S}$ and enhanced $\mathrm{O}$ signals. These results suggest a significant transformation of Cu-Co binary sulfides into oxides and hydroxides, as corroborated by the XRD patterns 
(Supplementary Fig. S4e), as well as Raman and X-ray photoelectron spectroscopy (XPS). An HR-TEM image of a hexagon-shaped nanosheet on CuCoSP shows a typical (101) facet of $\mathrm{Co}(\mathrm{OH})_{2}$ and some $\mathrm{Co}_{3} \mathrm{O}_{4}$ nanocrystals at the edge. The EDX mapping of CuCoSP shows an intertwined distribution of $\mathrm{Cu}$ and $\mathrm{Co}$ on the nanorod (Fig. 1f), and the linear EDX scan reveals a higher content of $\mathrm{Co}$ in the shell region (Fig. 1g). Therefore, the shell assembled by xagon-shaped nanosheets is a Co element-rich phase, and the redox activation might induce the redistribution of $\mathrm{Co}$-based and $\mathrm{Cu}$-based phases.

To investigate the spatial arrangement of $\mathrm{Cu}$-based and Cobased phases, we carried out XPS depth profiling. We calculated the atomic percentages of $\mathrm{Cu}, \mathrm{Co}, \mathrm{O}, \mathrm{S}$ and $\mathrm{P}$ in both CuCoSP_no and CuCoSP as a function of $\mathrm{Ar}^{+}$etching time (Fig. 1h and Supplementary Fig. S6). We found that the CuCoSP_no has a $\mathrm{Cu}-$ rich surface $(\mathrm{Co}: \mathrm{Cu}=0.862: 1)$ and Co-rich core $(\mathrm{Co}: \mathrm{Cu}=$ 1.83: 1 at $40 \mathrm{~min}$ etching time), which is in line with the EDXlinear scan results. The surface of $\mathrm{CuCoSP}$ is enriched with $\mathrm{Co}$ with a $\mathrm{Co} / \mathrm{Cu}$ ratio of 5.23: 1 . After 5 min etching time, the $\mathrm{Co} / \mathrm{Cu}$ ratio decreases to 3.07: 1 and slightly decreases in the following $35 \mathrm{~min}$ of $\mathrm{Ar}^{+}$etching. The results reveal an electrochemical redox activation-induced outward diffusion of Co ions and a relative inward diffusion of $\mathrm{Cu}$ ions, contributing to the phase separation in CuCoSP. The outward diffusion of Co ions is attributed to the easier oxidation of cobalt sulfides than copper sulfides into corresponding oxides or hydroxides. EDX mapping images of CuCoSP_no after one-cycle redox activation provide further evidence (Supplementary Fig. S7), with the maps of Co and $\mathrm{O}$ overlapping on the outer-shell layer and those of $\mathrm{Cu}$ and residual $S$ in the inner-core layer. This controllable phase separation in metal sulfide matrix driven by electrochemically redox activation may offer a strategy for a tandem catalyst design, which enables in situ formation of multiple active phases and rich phase interfaces for rapid spillover and transfer of reaction intermediates.

This core-shell arrangement of the Cu-based phases and Cobased phases, together with the rich phase interface between them, is the key to achieve a near-unity selectivity for subsequent $\mathrm{NO}_{3}{ }^{-}$-to- $\mathrm{NH}_{3}$ catalysis on $\mathrm{CuCoSP}$. The $\mathrm{Cu}$ foil substrate of $\mathrm{CuCoSP}$ may play a similar role to the $\mathrm{Cu}$-based phases (Fig. 1a). As a control, we used a $\mathrm{Cu}$ foil or ZIF-Co-R grown on carbon paper (CC) as precursors and treated them by the same EC-MOF and activation procedures (Supplementary Fig. S8). The related materials were denoted as CuSP and CoSP, respectively.

$\mathrm{NO}_{3}$ RR performance. Linear sweep voltammetry (LSV) and onehour electrolysis were performed for assessing the activity and selectivity of the as-synthesized catalysts in $0.01 \mathrm{M} \mathrm{KNO}_{3}$ and $0.1 \mathrm{M}$ $\mathrm{KOH}$ (pH 13) (Fig. 2a-c). Unless otherwise noted, all potentials are corrected vs the reversible hydrogen electrode (RHE). Performing $\mathrm{NO}_{3} \mathrm{RR}$ in alkaline media was chosen due to the reported lower probability of the formation of toxic intermediates in solution (e.g., nitrogen oxides and $\mathrm{NH}_{2} \mathrm{OH}$ ), as compared to those in acidic or neutral media, as well as the need of removing $\mathrm{NO}_{3}^{-}$ions in alkaline nuclear wastewater ${ }^{21,42}$. We set the concentration of nitrate to be $0.01 \mathrm{M}$, which ensures the concentration of formed $\mathrm{NH}_{3}$ to be easily higher than that of environmental contaminants which in turn helps to compare the intrinsic activity of the catalysts via bypassing the positive effects of high-concentration $\mathrm{NO}_{3}{ }^{-}$ (e.g., $1 \mathrm{M}$ ) with respect to facilitating the $\mathrm{NO}_{3} \mathrm{RR}^{52,68}$.

The LSV of CuSP in the presence of $\mathrm{NO}_{3}{ }^{-}$is similar to that of the $\mathrm{NO}_{3} \mathrm{RR}$ on the $\mathrm{Cu}(100)$ facet $^{42}$, where a diffusion-limited maximum total current density $\left(j_{\text {total }}\right)$ of $-55.3 \mathrm{~mA} / \mathrm{cm}^{-2}$ is reached at around $-0.3 \mathrm{~V}$. At $<-0.3 \mathrm{~V}$, the surface of CuSP becomes blocked by the strongly adsorbed intermediates of the
$\mathrm{H}_{2}$ evolution reaction (HER) and/or $\mathrm{NO}_{3} \mathrm{RR}$ until the surface is renewed because of the drastic HER at $<-0.6 \mathrm{~V}^{42}$. CoSP requires a $\sim 150 \mathrm{mV}$ more negative potential to drive the $\mathrm{NO}_{3} \mathrm{RR}$, but it shows a sharply increased $j_{\text {total }}$ for the HER at $<-0.2 \mathrm{~V}$, where metallic Co is supposedly formed (Supplementary Fig. S9). The CuCoSP has the catalytic features of both CuSP and CoSP, showing the highest $\mathrm{NO}_{3} \mathrm{RR}$ activity between $-0.16 \mathrm{~V}$ and $0.085 \mathrm{~V}$. Moreover, the Tafel slope of CuCoSP for the HER in $0.1 \mathrm{M} \mathrm{KOH}$ is $69 \mathrm{mV} \mathrm{dec}^{-1}$, and smaller than those of CuSP

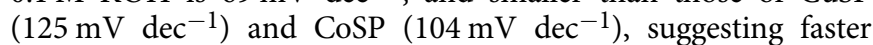
kinetics for the HER (Supplementary Fig. S9). Thus, there is a strong synergy between the $\mathrm{Cu}$-based and Co-based phases in CuCoSP for $\mathrm{NO}_{3} \mathrm{RR}$ at $>-0.2 \mathrm{~V}$ and HER at $<-0.2 \mathrm{~V}$.

Determination of the product selectivity for CuSP, CoSP and CuCoSP shows a significant difference in the FE for $\mathrm{NH}_{3}$ and $\mathrm{NO}_{2}{ }^{-}$(Fig. 2b, c and Supplementary Figs. S10-13). At low overpotentials $(>-0.2 \mathrm{~V})$, CuSP exclusively catalyzes the formation of $\mathrm{NO}_{2}{ }^{-}$, while CoSP shows a high inherent $\mathrm{NH}_{3}$ selectivity without any interference from the underlying CC (Supplementary Fig. S14d). The CuCoSP inherits the advantages of CoSP and reaches a maximum $\mathrm{FE}$ of $95.9 \%$ for $\mathrm{NH}_{3}$ at $-0.075 \mathrm{~V}, 14.5 \%$ higher than that of CoSP. This finding further suggests the synergy of the $\mathrm{Cu}$-based and Co-based phases in CuCoSP for selective $\mathrm{NO}_{3}{ }^{-}$-to- $\mathrm{NH}_{3}$ conversion. Moreover, the $\mathrm{CuCoSP}$ shows a FE of $88.7 \%$ for $\mathrm{NH}_{3}$ and an $\mathrm{NH}_{3}$ partial current densities $\left(j_{\mathrm{NH}}\right)$ of $-9.54 \mathrm{~mA} \mathrm{~cm}^{-2}$ at $-0.025 \mathrm{~V}$, a potential at which CuSP exhibits exclusive $\mathrm{NO}_{2}{ }^{-}$generation and CoSP shows a negligible $\mathrm{NO}_{3} \mathrm{RR}$ activity (Fig. 2a-d and Supplementary Figs. S11-13). CuCoSP retains this advantage even at $0.025 \mathrm{~V}$ (a FE of $66.4 \%$ for $\mathrm{NH}_{3}$ and $\mathrm{a}_{\mathrm{NH} 3}$ of $-3.84 \mathrm{~mA} \mathrm{~cm}^{-2}$ ). Similar to CuSP, the $\mathrm{Cu}$ foil and inner Cu-based phases of CuCoSP can catalyze the preferential formation of $\mathrm{NO}_{2}{ }^{-}$, which might then be further reduced to $\mathrm{NH}_{3}$ at the outer Co-based phases. This hypothesis, as further demonstrated below, may well account for the $\sim 2$-fold higher $j_{\mathrm{NH} 3}$ for CuCoSP than that of CoSP at $>-0.175 \mathrm{~V}$ (Fig. 2d).

At higher overpotentials $(<-0.2 \mathrm{~V}), \mathrm{CuCoSP}$ and CoSP show a sharp decline of the $\mathrm{FE}$ for $\mathrm{NH}_{3}$ but minor changes in their $\mathrm{FE}$ for $\mathrm{NO}_{2}^{-}(<1 \%)$ (Fig. 2b-d), indicating that the $\mathrm{NO}_{3} \mathrm{RR}$ on CuCoSP and CoSP is challenged by the drastically enhanced HER (Supplementary Fig. S9). The competing HER was previously suppressed by increasing the $\mathrm{NO}_{3}{ }^{-}$concentrations and/or the $\mathrm{pH}$ value of electrolytes ${ }^{45,52}$. As anticipated, $j_{\text {total }}$ of CuCoSP linearly increases with the $\mathrm{NO}_{3}{ }^{-}$concentrations (Supplementary Fig. S15), indicative of a first-order reaction kinetics. At $-0.175 \mathrm{~V}$, the $\mathrm{CuCoSP}$ catalyst reaches a nearly equal $\mathrm{FE}$ of $93.3 \pm 2.1 \%$ for $\mathrm{NH}_{3}$ and a linearly increased $\mathrm{NH}_{3}$ yield rate $\left(\mathrm{Y}_{\mathrm{NH}}\right)$ with a value of 15.7, $33.4,74.1,155$ and $327 \mu \mathrm{mol} \mathrm{h}^{-1} \mathrm{~cm}^{-2}$ in $1,2,5,10$ and $20 \mathrm{mM}$ $\mathrm{NO}_{3}{ }^{-}$, respectively (Fig. 2e). When the $\mathrm{NO}_{3}{ }^{-}$concentration increases to 50 and $100 \mathrm{mM}$, the $\mathrm{Y}_{\mathrm{NH} 3}$ of $\mathrm{CuCoSP}$ reaches 0.690 and $1.17 \mathrm{mmol} \mathrm{h}^{-1} \mathrm{~cm}^{-2}$, respectively. The latter is comparable to the highest reported value of $1.17 \mathrm{mmol} \mathrm{h}^{-1} \mathrm{~cm}^{-2}$ on strained $\mathrm{Ru}$ nanoclusters evaluated at $-0.2 \mathrm{~V}$ in $1 \mathrm{M} \mathrm{NO}_{3}{ }^{-}$and $1 \mathrm{M} \mathrm{KOH}(\mathrm{pH}$ $14)^{52}$. The turnover numbers (TON) of nitrate on CuCoSP, defined by the ratio of the yielded $\mathrm{NH}_{3}$ concentration $\left[\mathrm{NH}_{3}\right]$ to the converted $\mathrm{NO}_{3}^{-}$concentration $\left[\mathrm{NO}_{3}^{-}\right]$, are close to 1 at $\left[\mathrm{NO}_{3}{ }^{-}\right]<20 \mathrm{mM}$. This indicates that the formed $\mathrm{NH}_{3}$ is mainly derived from the $\mathrm{NO}_{3}^{-}$electroreduction rather than any environmental contaminations (Fig. 2e and Supplementary Fig. S15d). However, the TON value decreases to $\sim 0.8$ in $100 \mathrm{mM}$ nitrate electrolytes, suggesting that high $\left[\mathrm{NO}_{3}{ }^{-}\right]$might induce the formation of gaseous by-products (e.g., $\mathrm{N}_{2}$ and $\left.\mathrm{NO}_{\mathrm{x}}\right)^{36}$. Finally, the CuCoSP achieves a half-cell energy efficiency of $\mathrm{NH}_{3}$ $\left(\mathrm{EE}_{\mathrm{NH} 3}\right)$ close to $40 \%$. These results endow the proposed CuCoSP ranking among the best $\mathrm{NH}_{3}$ synthesizing electrocatalysts (Supplementary Table S1). 



Fig. $2 \mathrm{NO}_{3}{ }^{-}$-to- $\mathrm{NH}_{3}$ conversion performance. LSVs at a scan rate of $5 \mathrm{mV} \mathrm{s}^{-1}$ (a), Faradaic efficiencies (FE) for $\mathrm{NH}_{3}(\mathbf{b})$ and $\mathrm{NO}_{2}{ }^{-}$(c) on CuSP, CoSP and CuCoSP in $0.01 \mathrm{M} \mathrm{NO}_{3}-$ and $0.1 \mathrm{M} \mathrm{KOH}(\mathrm{pH} 13)$ at various applied potentials. $\mathbf{d} \mathrm{A}$ comparison of half-cell energy efficiencies of $\mathrm{NH}_{3}\left(\mathrm{EE}_{\mathrm{NH}_{3}}\right)$ and partial current densities of $\mathrm{NH}_{3}\left(\mathrm{NHH}_{3}\right)$ on CuSP, CoSP and CuCoSP catalysts at various potentials. e The FE of $\mathrm{NO}_{2}{ }^{-}$and $\mathrm{NH}_{3}$, the $\mathrm{NH}_{3}$ yield rate $\left(\mathrm{Y}_{\mathrm{NH} 3}\right)$, as well as the ratio of the formed $\mathrm{NH}_{3}$ concentration $\left[\mathrm{NH}_{3}\right]$ to the converted $\mathrm{NO}_{3}{ }^{-}$concentration $\left[\mathrm{NO}_{3}{ }^{-}\right]$on the CuCoSP catalyst at $-0.175 \mathrm{~V}$ vs. $\mathrm{RHE}$ at $\left[\mathrm{NO}_{3}{ }^{-}\right]$in the range of $1-100 \mathrm{mM}$ at pH 13. f The ECSA-normalized $\mathrm{Y}_{\mathrm{NH} 3}$ on CuSP, CoSP, CuCoSP and metallic CuCo hybrids in $0.01 \mathrm{M} \mathrm{NO}_{3}^{-}$and $0.1 \mathrm{M} \mathrm{KOH}^{-}$at various potentials. Error bars denote the standard deviations calculated from three independent measurements.

To assess the origin of the detected $\mathrm{NH}_{3}$ and correct the $\mathrm{Y}_{\mathrm{NH} 3}$, we employed ${ }^{1} \mathrm{H}$ NMR to detect the $\mathrm{NH}_{3}$ generation on $\mathrm{CuCoSP}$ in $0.1 \mathrm{M} \mathrm{KOH}$ containing $0.01 \mathrm{M}{ }^{15} \mathrm{~N}$-labelled ${ }^{15} \mathrm{NO}_{3}{ }^{-}$or ${ }^{14} \mathrm{NO}_{3}{ }^{-}$(Supplementary Fig. S16). The ${ }^{14} \mathrm{NH}_{3}$ yield quantified by ${ }^{1} \mathrm{H}$ NMR is very close to that determined by colorimetric methods ${ }^{69}$, confirming the reliability of our results. The negligible $\mathrm{NH}_{3}$ generation in blank $0.1 \mathrm{M} \mathrm{KOH}$ and the typical ${ }^{1} \mathrm{H}$ NMR double peaks of ${ }^{15} \mathrm{NH}_{4}{ }^{+}$after the electrolysis of ${ }^{15} \mathrm{NO}_{3}{ }^{-}$suggest that the obtained $\mathrm{NH}_{3}$ indeed originates from the $\mathrm{NO}_{3} \mathrm{RR}^{25,28,44}$.

To derive the intrinsic activities of the catalysts, we normalize their $\mathrm{Y}_{\mathrm{NH} 3}$ by the electrochemical active surface area (ECSA) (correlated with the double-layer capacity $\left(\mathrm{C}_{\mathrm{dl}}\right)$ ) (Fig. $2 \mathrm{f}$ and Supplementary Fig. S17). At low overpotentials, the $\mathrm{Y}_{\mathrm{NH} 3}$ of CuCoSP can be $\sim 45$ times and two orders of magnitude higher than those of CoSP and CuSP, respectively, confirming the high intrinsic performance of CuCoSP. Remarkably, CuSP lost activity rapidly at $>-0.525 \mathrm{~V}$ during the $\mathrm{NO}_{3}{ }^{-}$electrolysis (Supplementary Fig. S11), which occurred neither at CoSP nor at CuCoSP (Supplementary Fig. S12 and S13). This finding indicates that the Co-based phases existing in CoSP and CuCoSP may help to avoid similar poisoning effects. When the $\mathrm{NO}_{3} \mathrm{RR}$ was performed at $-0.175 \mathrm{~V}$ for $10 \mathrm{~h}$ over the CuCoSP catalyst, no appreciable decay in activity and selectivity for $\mathrm{NO}_{3}{ }^{-}$-to- $\mathrm{NH}_{3}$ conversion was observed, and the structural features of $\mathrm{CuCoSP}$ were retained (Supplementary Fig. S18).

Understanding the high-rate $\mathrm{NH}_{3}$ generation on CuCoSP. Electrocatalytic $\mathrm{NO}_{3} \mathrm{RR}$ follows a consecutive pathway (Fig. 3a), where $\mathrm{NO}_{2}{ }^{-}$is generated as a stable intermediate ${ }^{17,36}$. A fast $\mathrm{NO}_{3}{ }^{-}$-to- $\mathrm{NH}_{3}$ conversion requires the simultaneous acceleration of the sequential $\mathrm{NO}_{3}{ }^{-}$-to- $\mathrm{NO}_{2}{ }^{-}$and $\mathrm{NO}_{2}{ }^{-}$-to- $\mathrm{NH}_{3}$ reactions ${ }^{35,36}$. To rationalize the high $\mathrm{Y}_{\mathrm{NH} 3}$ on CuCoSP at low overpotentials, we firstly compared the potentials of the three catalysts required to reach $-1 \mathrm{~mA} \mathrm{~cm}^{-2}$ (kinetic area with negligible mass transport limitation) in $0.01 \mathrm{M} \mathrm{NO}_{3}{ }^{-}$and $\mathrm{NO}_{2}{ }^{-}$, respectively (Supplementary Fig. S20). CuSP shows a $176 \mathrm{mV}$ more positive potential than CoSP for $\mathrm{NO}_{3}{ }^{-}$reduction, while CoSP has a $251 \mathrm{mV}$ more positive potential than CuSP for $\mathrm{NO}_{2}{ }^{-}$reduction. Therefore, CuSP and CoSP may play a complementary role for the consecutive $\mathrm{NO}_{3} \mathrm{RR}$. Significantly, CuCoSP combines the positive properties of CuSP and CoSP for $\mathrm{NO}_{3}{ }^{-}$and $\mathrm{NO}_{2}{ }^{-}$reduction, respectively, implying that there are likely two types of active phases in CuCoSP: Cu-based phases which are similar to those in CuSP, and Co-based phases which are similar to those in CoSP. The two types of active phases in CuCoSP synergistically catalyze the tandem $\mathrm{NO}_{3} \mathrm{RR}$.

To validate this hypothesis, we further evaluated the rate constants $\mathrm{k}_{1}$ and $\mathrm{k}_{2}$ of each catalyst for $\mathrm{NO}_{3}{ }^{-}$-to- $-\mathrm{NO}_{2}{ }^{-}$and $\mathrm{NO}_{2}{ }^{-}$-to- $\mathrm{NH}_{3}$ conversion, respectively (Supplementary Fig. S21 and Table S2). We found that the rate constants of the three catalysts follow a similar trend as their potentials at $-1 \mathrm{~mA} \mathrm{~cm}^{-2}$; a larger rate constant corresponding to a more positive potential for reaching $-1 \mathrm{~mA} \mathrm{~cm}^{-2}$ (Fig. 3a). The largest $\mathrm{k}_{1}$ but the smallest $\mathrm{k}_{2}$ values of CuSP correspond to a fast reduction of $\mathrm{NO}_{3}{ }^{-}$to $\mathrm{NO}_{2}{ }^{-}$and subsequent desorption of $\mathrm{NO}_{2}{ }^{-}$to the electrolyte, resulting in the observed high $\mathrm{FE}$ of $\mathrm{NO}_{2}{ }^{-}$(Fig. $2 \mathrm{c}$ and Supplementary Fig. S11). On the CuCoSP surface, $\mathrm{NO}_{2}{ }^{-}$ intermediates are preferentially formed on $\mathrm{Cu}$-based phases and then spilt over to nearby Co-based phases. Compared to the $\mathrm{k}_{2} / \mathrm{k}_{1}$ ratio of CuSP (0.468), the larger $\mathrm{k}_{2} / \mathrm{k}_{1}$ ratios of CoSP (3.14) and CuCoSP (1.78) suggest a fast reduction of the intermediate $\mathrm{NO}_{2}{ }^{-}$ to $\mathrm{NH}_{3}$ over their Co-based phases, thus well explaining their near-unity selectivity for $\mathrm{NH}_{3}$ generation. We used the $\mathrm{k}_{1}$ values of CoSP and CuCoSP to estimate their local surface $\mathrm{NO}_{2}{ }^{-}$ concentration during the $\mathrm{NO}_{3} \mathrm{RR}$ and find a 1.54-fold higher value on CuCoSP than on CoSP (Supplementary Table S2), which 

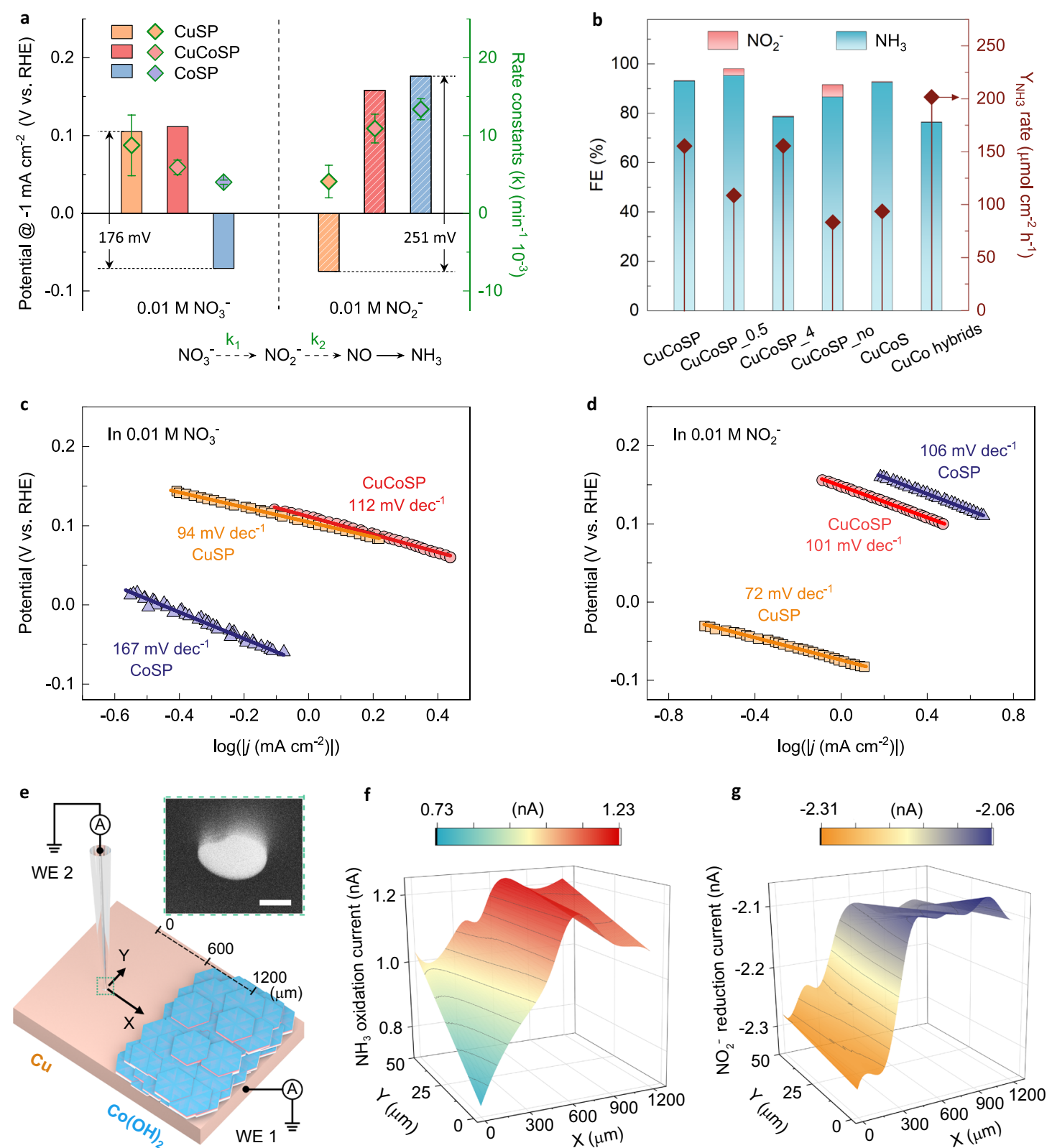

Fig. 3 Evaluation of the reaction kinetics and mechanisms of the catalysis of the $\mathbf{N O}_{3} \mathbf{R R}$. a The LSV-derived potentials at a current density of $-1 \mathrm{~mA} \mathrm{~cm}^{-2}$ and the calculated reaction constants ( $\mathrm{k}, \mathrm{k}_{1}$ for $\mathrm{NO}_{3}{ }^{-}$-to- $\mathrm{NO}_{2}{ }^{-}$and $\mathrm{k}_{2}$ for $\mathrm{NO}_{2}{ }^{-}$-to- $\mathrm{NO}$ conversion) for $\mathrm{NO}_{3}{ }^{-}$and $\mathrm{NO}_{2}{ }^{-}$reduction on $\mathrm{CuSP}$, CoSP and CuCoSP catalysts. $\mathrm{k}$ was calculated based on the concentration evolution of $\mathrm{NO}_{3}{ }^{-}$or $\mathrm{NO}_{2}{ }^{-}$ions as a function of electrolysis time at $-0.175 \mathrm{~V}$ vs. $\mathrm{RHE}$ in $0.01 \mathrm{M} \mathrm{NO}_{3}{ }^{-}$and $\mathrm{NO}_{2}{ }^{-}$at $\mathrm{pH}$ 13. Error bars denote the standard deviations of $\mathrm{k}$ calculated at different time points during $1 \mathrm{~h}$ electrolysis.

b A comparison of the FE and the $\mathrm{Y}_{\mathrm{NH} 3}$ on the control catalysts: CuCoSP_0.5, CuCoSP_4, CuCoSP_no, CuCoS and metallic CuCo hybrids. The LSV-derived Tafel slopes of CuSP, CoSP and CuCoSP in $0.01 \mathrm{M}$ nitrate (c) and nitrite (d) at pH 13, respectively. The LSVs were recorded at a scan rate of $1 \mathrm{mV} \mathrm{s}^{-1}$. e Schematic representation of the SECM setup that is operated in a sample generation-tip collection (SG-TC) mode using a Pt-UME (WE 2) to detect $\mathrm{NO}_{2}{ }^{-}$and $\mathrm{NH}_{3}$ produced during $\mathrm{NO}_{3} \mathrm{RR}$ on $\mathrm{Cu}_{-} \mathrm{Co}(\mathrm{OH})_{2}$ model catalyst (WE 1). Inset: SEM image of Pt-UME tip; scale bar is $500 \mathrm{~nm}$. $\mathbf{f}, \mathbf{g}$ Current maps of $\mathrm{NH}_{3}$ oxidation (f) and $\mathrm{NO}_{2}{ }^{-}$reduction ( $\mathbf{g}$ ) recorded at $0.76 \mathrm{~V}$ and $0.06 \mathrm{~V}$ (vs. RHE) at the Pt-UME, respectively, when a potential of $-0.12 \mathrm{~V}$ (vs. $\mathrm{RHE}$ ) is applied to the $\mathrm{Cu} \_\mathrm{Co}(\mathrm{OH})_{2}$ model catalyst in $50 \mathrm{mM} \mathrm{NO}_{3}^{-}$at $\mathrm{pH} 13$.

is consistent with the observed 1.66-fold larger $j_{\mathrm{NH} 3}$ of CuCoSP compared to CoSP at $-0.175 \mathrm{~V}$ (Fig. 2d). This finding unveils the crucial role of $\mathrm{Cu}$-based phases in CuCoSP for creating a high local $\mathrm{NO}_{2}{ }^{-}$concentration, which accelerates subsequent $\mathrm{NH}_{3}$ generation on its Co-based phases, ultimately contributing to the tandem catalysis of $\mathrm{NO}_{3} \mathrm{RR}$.

Considering the lowest $k_{1}$ value of CoSP, the smaller $k_{1}$ value of CuCoSP than CuSP can be rationalized since the less active Cobased phases of CuCoSP may block its active $\mathrm{Cu}$-based phases (especially the $\mathrm{Cu}$ foil substrate) for $\mathrm{NO}_{3}{ }^{-}$reduction. As such, we synthesized the CuCoSP_0.5 and CuCoSP_4 with $0.5 \mathrm{~h}$ and $4 \mathrm{~h}$ growth of ZIF-Co-R on $\mathrm{Cu}$ foil, respectively. The CuCoSP_0.5 shows catalytic features close to CuSP, thus giving a higher FE for $\mathrm{NO}_{2}{ }^{-}$than CuCoSP (Fig. 3b and Supplementary Fig. S22). This finding indicates that possible $\mathrm{Co}$ doping in $\mathrm{Cu}-$ based phases of CuCoSP_0.5 does not change their catalytic nature. Likewise, the CuCoSP_4 shows a similar catalytic feature to CoSP with a low sum $\mathrm{FE}$ for $\mathrm{NO}_{3} \mathrm{RR}$. Therefore, the content ratio of $\mathrm{Cu}$-based and Co-based phases in CuCoSP, rather than the $\mathrm{Cu}$ or $\mathrm{Co}$ doping, determines the rates of the $\mathrm{NO}_{3}{ }^{-}$-to- $\mathrm{NO}_{2}{ }^{-}$ 
and $\mathrm{NO}_{2}{ }^{-}$-to- $\mathrm{NH}_{3}$ reactions. This is a typical feature of tandem catalysts $^{39,59}$.

Electrokinetic analysis was conducted to determine the ratedetermining step (RDS) of the $\mathrm{NO}_{3}{ }^{-}$and $\mathrm{NO}_{2}{ }^{-}$reduction catalyzed by the three catalysts. In $0.01 \mathrm{M} \mathrm{NO}_{3}{ }^{-}$(Fig. 3c), CuSP and CuCoSP show Tafel slopes of 94 and $112 \mathrm{mV} \mathrm{dec}^{-1}$, respectively, a little lower than $120 \mathrm{mV} \mathrm{dec}^{-1}$, suggesting that the $\mathrm{RDS}$ is the first one-electron transfer occurring during the $\mathrm{NO}_{3}{ }^{-}$to- $\mathrm{NO}_{2}{ }^{-}$conversion ${ }^{34,48,70}$. The much higher Tafel slope of CoSP $\left(167 \mathrm{mV} \mathrm{dec}{ }^{-1}\right)$ indicates that the $\mathrm{NO}_{3} \mathrm{RR}$ over CoSP is limited by the initial adsorption and activation of $\mathrm{NO}_{3}{ }^{-48}$. In $0.01 \mathrm{M}$ $\mathrm{NO}_{2}{ }^{-}$(Fig. 3d), CoSP and CuCoSP show Tafel slopes of 106 and $101 \mathrm{mV} \mathrm{dec}{ }^{-1}$, respectively, suggesting that the RDS is the first one-electron transfer for the reduction of $\mathrm{NO}_{2}{ }^{-}$to $\mathrm{NO}^{34,48}$. CuSP has a Tafel slope of $72 \mathrm{mV} \mathrm{dec}^{-1}$, close to the critical value of $60 \mathrm{mV} \mathrm{dec}-1$, implying that the RDS is a chemical step 71,72 . Based on the theoretical $\mathrm{NO}_{3} \mathrm{RR}$ pathways on $\mathrm{Cu}^{44}$, this $\mathrm{RDS}$ is likely the coupling of strongly adsorbed ${ }^{*} \mathrm{NO}$ and ${ }^{*} \mathrm{H}$. Remarkably, the smaller Tafel slope of CuSP than those of CoSP and CuCoSP points to a faster $\mathrm{NO}_{2}{ }^{-}$reduction kinetics on CuSP, but CuSP suffers from a faster deactivation in $0.01 \mathrm{M} \mathrm{NO}_{2}{ }^{-}$than in $0.01 \mathrm{M} \mathrm{NO}_{3}^{-}$(Supplementary Fig. S21), thus giving the smallest apparent $k_{2}$ value. Accordingly, the observed poisoning of CuSP might be ascribed to the strongly adsorbed ${ }^{*} \mathrm{NO}$ species. Therefore, CuCoSP combines the nature of CuSP for $\mathrm{NO}_{3}{ }^{-}$ reduction with that of $\mathrm{CoSP}$ for $\mathrm{NO}_{2}{ }^{-}$reduction.

To assess the possible roles of anionic ligands $\left(\mathrm{PO}_{4}{ }^{3-}\right.$ and $\left.\mathrm{S}^{2-}\right)$ in our system, we tested the $\mathrm{NO}_{3} \mathrm{RR}$ performance of CuCoSP_no catalysts with the maximum $\mathrm{PO}_{4}{ }^{3-}$ and $\mathrm{S}^{2-}$ ligands and $\mathrm{CuCoS}$ catalysts with only $\mathrm{S}^{2-}$ ligand. The lower $\mathrm{FE}$ (for $\mathrm{NH}_{3}$ ) and $\mathrm{Y}_{\mathrm{NH} 3}$ of CuCoSP_no compared with those of CuCoSP (Fig. 3b), in combination with the near-unity $\mathrm{NH}_{3}$ selectivity but low $\mathrm{Y}_{\mathrm{NH} 3}$ of $\mathrm{CuCoS}$ (Fig. $3 \mathrm{~b}$ and Supplementary Fig. S23), suggest that $\mathrm{PO}_{4}{ }^{3-}$ and $\mathrm{S}^{2-}$ ligands most likely do not play a prominent role. We evaluated the final morphology of CuCoSP after repeating three electrolysis of one hour at $-0.325 \mathrm{~V}$ and observed a separation of $\mathrm{Cu}$-based phases (nanorods) and Co-based phases (hexagonal nanosheets) based on EDX mapping and HR-TEM images (Supplementary Fig. S24). This result rules out the formation of a bulk $\mathrm{CuCo}$ alloy, as corroborated by the XRD patterns (Supplementary Fig. S4f). To identify the impact of surface $\mathrm{CuCo}$ metallizing and/or alloying possibly during the $\mathrm{NO}_{3} \mathrm{RR}$, we electrodeposited a hybrid of $\mathrm{Cu}-\mathrm{Co}$ metals and alloy (Co: $\mathrm{Cu}=$ 2.82: 1, close to that on CuCoSP surface) on CC (Supplementary Fig. S25). The metallic CuCo hybrids show Tafel slopes of $61 \mathrm{mV}$

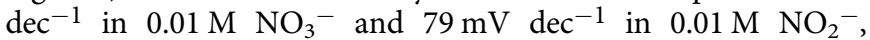
indicating a significantly different catalytic mechanism and kinetics than CuCoSP. Despite its higher apparent $\mathrm{Y}_{\mathrm{NH} 3}$, the CuCo hybrids have a lower FE for $\mathrm{NH}_{3}$ and ECSA-normalized $\mathrm{Y}_{\mathrm{NH} 3}$ than CuCoSP (Fig. $2 \mathrm{f}$ and $3 \mathrm{~b}$ ). The ECSA-normalized $\mathrm{Y}_{\mathrm{NH} 3}$ of CuCo hybrids is about 85 and $67 \%$ of that formed on CuCoSP at $-0.175 \mathrm{~V}$ and $-0.025 \mathrm{~V}$, respectively. As such, the excellent intrinsic performance of CuCoSP towards $\mathrm{NH}_{3}$ generation, especially at low overpotentials, is unlikely from surface $\mathrm{Cu}-\mathrm{Co}$ metallizing or alloying. It can be concluded that the high-rate $\mathrm{NO}_{3}{ }^{-}$-to- $\mathrm{NH}_{3}$ conversion on CuCoSP is due to the coexistence of the complementary $\mathrm{Cu}$-based and Co-based phases: the former catalyzes $\mathrm{NO}_{3}{ }^{-}$-to- $\mathrm{NO}_{2}{ }^{-}$reduction and the latter catalyzes the $\mathrm{NO}_{2}{ }^{-}$-to- $\mathrm{NH}_{3}$ conversion, contributing to the tandem catalysis of $\mathrm{NO}_{3} \mathrm{RR}$.

To offer a direct evidence for this tandem catalysis of $\mathrm{NO}_{3} \mathrm{RR}$, we performed SECM experiments in a surface-generation tipcollection mode, which involves using a positioned $\mathrm{Pt}$ ultramicroelectrode (Pt-UME) to detect the $\mathrm{NO}_{2}{ }^{-}$and $\mathrm{NH}_{3}$ formed on the surface of a $\mathrm{Cu}_{-} \mathrm{Co}(\mathrm{OH})_{2}$ model catalyst (Fig. 3e) during the $\mathrm{NO}_{3}{ }^{-}$electrolysis. This $\mathrm{Cu} \_\mathrm{Co}(\mathrm{OH})_{2}$ model catalyst has two adjacent layers to simulate the CuSP ( $\mathrm{Cu}$ layer) and CoSP $\left(\mathrm{Co}(\mathrm{OH})_{2}\right.$ layer) catalysts, while the border between the two layers may play a similar role of as the adjacent phases in CuCoSP (Supplementary Fig. S26). During the SECM measurements, the catalyst layer was polarized to $-0.12 \mathrm{~V}$ (vs. RHE), while at the positioned Pt-UME cyclic voltammetry (CV) in the potential range between $-0.12 \mathrm{~V}$ and $1.58 \mathrm{~V}$ (vs. RHE) at a rate of $200 \mathrm{mV} \mathrm{s}^{-1}$ was performed. We were applying $-0.12 \mathrm{~V}$ at catalysts as we found that at this potential, CuSP and CoSP is relatively more stable and active compared to potentials of $-0.075 \mathrm{~V}$ and $-0.025 \mathrm{~V}$, which is beneficial for in situ detection of the intermediately formed $\mathrm{NO}_{2}{ }^{-}$and $\mathrm{NH}_{3}$. The same reason is the use of a concentration of $50 \mathrm{mM} \mathrm{NO}_{3}{ }^{-}$. At $-0.12 \mathrm{~V}$, CuSP mainly produces $\mathrm{NO}_{2}{ }^{-}$, and CoSP exhibits a much lower $\mathrm{NO}_{3} \mathrm{RR}$ activity compared to CuCoSP, as indicated in Fig. 2a-c and Supplementary Fig. S11-13.

We firstly performed cyclic voltammograms at the Pt-UME separately in $10 \mathrm{mM} \mathrm{NO}_{3}{ }^{-}, \mathrm{NO}_{2}{ }^{-}$and $\mathrm{NH}_{4} \mathrm{Cl}$ at $\mathrm{pH} \mathrm{13}$, which are compared with those in pure $0.1 \mathrm{M} \mathrm{KOH}$ (Supplementary Fig. S27a-c). The results indicate that the Pt-UME does not exhibit any activity for the $\mathrm{NO}_{3} \mathrm{RR}$, but it can efficiently catalyze $\mathrm{NO}_{2}{ }^{-}$reduction and $\mathrm{NH}_{3}$ oxidation in alkaline media, which is well consistent with previous studies ${ }^{73-75}$. This enables selectively detecting the in situ generated $\mathrm{NO}_{2}{ }^{-}$(at $0.06 \mathrm{~V}$ ) and $\mathrm{NH}_{3}$ (at $0.76 \mathrm{~V}$ ) (Supplementary Fig. S27d-f), when the tip of Pt-UME approaches the surface of $\mathrm{Cu} \_\mathrm{Co}(\mathrm{OH})_{2}$ layer. Accordingly, a high current from $\mathrm{NH}_{3}$ oxidation and $\mathrm{NO}_{2}{ }^{-}$reduction corresponds to a high local concentration of $\mathrm{NH}_{3}$ and $\mathrm{NO}_{2}{ }^{-}$, respectively, above the surface of $\mathrm{Cu}_{-} \mathrm{Co}(\mathrm{OH})_{2}$ catalyst. The SECM array scans (Fig. 3f, g) reveal that the amount of generated $\mathrm{NH}_{3}$ is substantially increasing at the border $(\mathrm{X} \approx 600 \mu \mathrm{m})$ between the $\mathrm{Cu}$ and $\mathrm{Co}(\mathrm{OH})_{2}$ layers, accompanying by a sharply decreased amount of generated $\mathrm{NO}_{2}{ }^{-}$. The SECM results unequivocally confirmed that the $\mathrm{NO}_{2}{ }^{-}$is preferentially formed on the $\mathrm{Cu}$ layer and then diffuses to the near $\mathrm{Co}(\mathrm{OH})_{2}$ layer, where the $\mathrm{NO}_{2}{ }^{-}$is reduced into $\mathrm{NH}_{3}$ according to a typical tandem catalysis process. Note that the formed $\mathrm{NH}_{3}$ at the border of the $\mathrm{Cu} \_\mathrm{Co}(\mathrm{OH})_{2}$ layers diffuses to both sides, leading to the formation of a concentration gradient around the border during the course of the SECM measurement.

Identification of the active phases for $\mathrm{NO}_{3} \mathrm{RR}$. Ex situ XPS and Raman spectra were obtained to identify the surface phase compositions of the three catalysts (Fig. 4, Supplementary Fig. S28 and Fig. S29). We find that the redox activation induced the transformation of the initial $\mathrm{Cu} / \mathrm{Co}$-based sulfide phases into the corresponding oxides and hydroxides (see detailed assignments of the XPS and Raman peaks in Supplementary Notes 1 and 2). As a result, CuSP consists of $\mathrm{Cu}^{0}, \mathrm{CuO}, \mathrm{Cu}_{2} \mathrm{O}$ and $\mathrm{Cu}(\mathrm{OH})_{2}{ }^{53,54,76}$, whereas CoSP is composed of $\mathrm{Co}^{2+}$-dominated $\mathrm{CoO}$ and $\mathrm{Co}(\mathrm{OH})_{2}$, as well as $\mathrm{Co}^{3+}{ }_{\text {-containing }} \mathrm{Co}_{3} \mathrm{O}_{4}$ and $\mathrm{CoOOH}^{65,77-79}$. As anticipated, CuCoSP exists as a combination of CuSP and CoSP in phase compositions, except for the observed suppression of $\mathrm{Co}^{3+}-\mathrm{CoO}_{x}$ phases and increase of $\mathrm{Cu}(\mathrm{OH})_{2}$ phases (Fig. $4 \mathrm{a}$, b), which points to the synergy interaction between $\mathrm{Cu}$-based and Co-based phases in CuCoSP. O $1 s$ XPS spectra reveal a $\sim 2$-fold higher content of O vacancies on CuSP and CuCoSP than on CoSP (Fig. 4c and Supplementary Fig. S28c) ${ }^{80}$. Together with the observed smaller Tafel slopes of CuSP and CuCoSP compared to CoSP (Supplementary Fig. S28f), this result highlights a potential role of $\mathrm{O}$ vacancies in $\mathrm{Cu}$-based phases for the initial adsorption and/or activation of free $\mathrm{NO}_{3}{ }^{-}$ions ${ }^{50}$, which is a key challenge for most of the reported $\mathrm{NO}_{3} \mathrm{RR}$ catalysts.

To derive the active phases for $\mathrm{NO}_{3} \mathrm{RR}$ experimentally, we used in situ Raman spectroscopy to monitor the phase evolution of the 

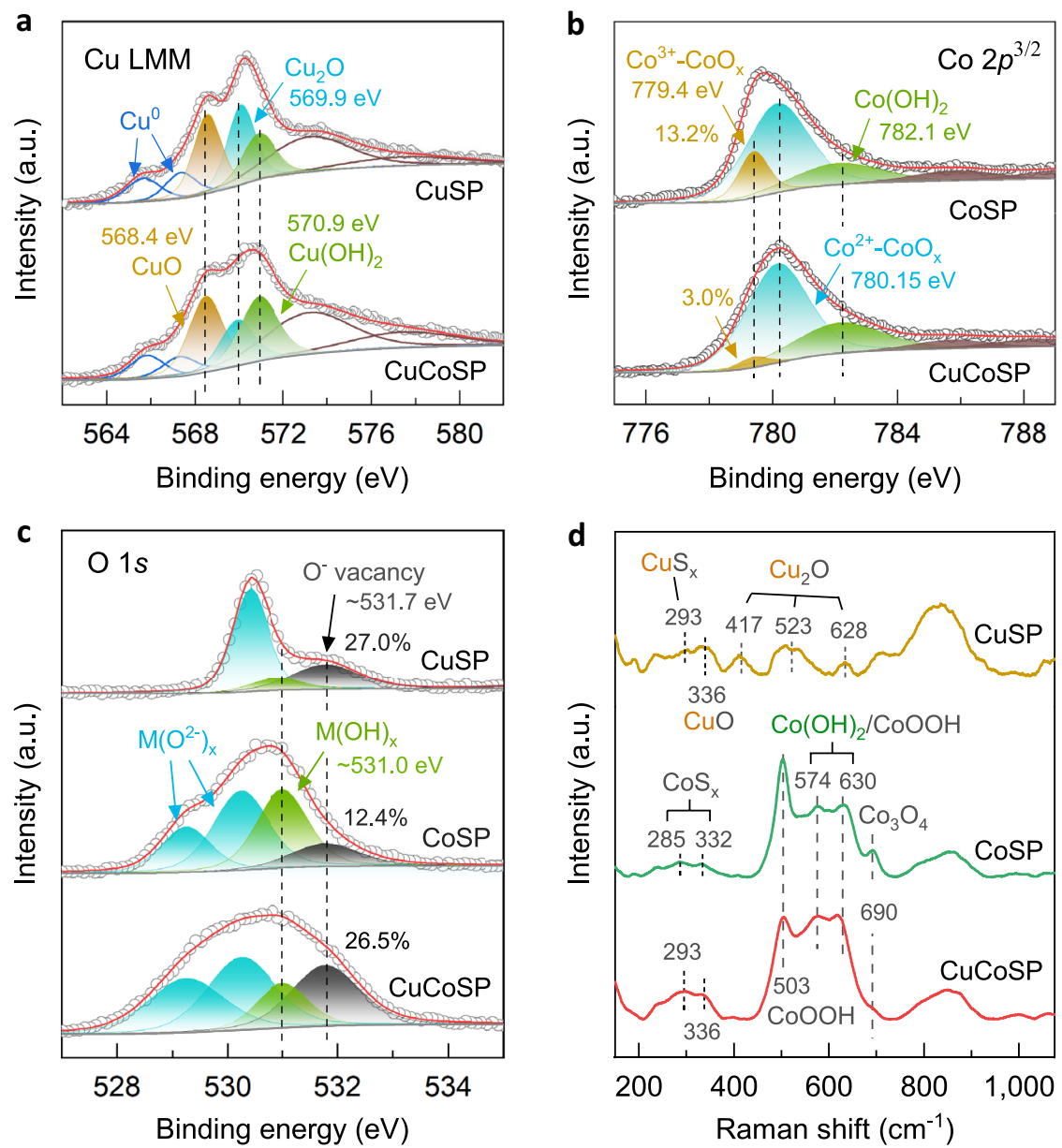

Fig. 4 Surface phase compositions of CuSP, CoSP and CuCoSP catalysts. Cu LMM (a), Co $2 p^{3 / 2}$ (b) and O 1s (c) XPS spectra. d Ex situ Raman spectra.

three catalysts at a series of applied potentials in $0.01 \mathrm{M} \mathrm{KOH}$ in the presence or absence of $0.01 \mathrm{M} \mathrm{NO}_{3}^{-}$(Fig. 5 and Supplementary Fig. S30). $\mathrm{NO}_{3}{ }^{-}$ions exhibit a characteristic peak at $\sim 1050 \mathrm{~cm}^{-1} 81 . \mathrm{K}_{2} \mathrm{SO}_{4}$ was added to ensure sufficient ionic conductivity and provides $\mathrm{SO}_{4}{ }^{2-}$ ions as an external Raman reference with a typical signal at $\sim 982 \mathrm{~cm}^{-1} 53$.

Figure $5 \mathrm{a}$ shows the Raman spectra of CuSP at reducing potentials related to $\mathrm{NO}_{3} \mathrm{RR}$. The initial broad bands at 417, 523 and $628 \mathrm{~cm}^{-1}$, associated with $\mathrm{Cu}_{2} \mathrm{O}$ phases ${ }^{53,54}$, persist at as low as $-0.525 \mathrm{~V}$. Remarkably, at $<-0.175 \mathrm{~V}$, two sets of peaks emerge at $341,407,491$ and $524 \mathrm{~cm}^{-1}$, previously assigned to $\mathrm{Cu}-\mathrm{O}$ and $\mathrm{Cu}-\mathrm{OH}$ modes, respectively ${ }^{53}$. The same but more notable signals are observed in the absence of $\mathrm{NO}_{3}^{-}$(Supplementary Fig. S30a), partly due to the $\mathrm{NO}_{3} \mathrm{RR}$ delaying the surface phase evolution. It is worth noting that CuSP can prevent poisoning only at < $-0.425 \mathrm{~V}$, where the surface evolution of CuSP might promote stable $\mathrm{NH}_{3}$ generation. As a control, we further assessed the performance of a metallic $\mathrm{Cu}$ foil for $\mathrm{NO}_{3} \mathrm{RR}$ (Supplementary Fig. S14). The results show that at potentials $>-0.425 \mathrm{~V}, \mathrm{Cu}$ foil suffered from deactivation in a much higher rate, compared to CuSP containing mixed $\mathrm{Cu} / \mathrm{CuO}_{\mathrm{x}}$ phases. Moreover, at low overpotentials, the $\mathrm{Cu}$ foil mainly electrochemically catalyzes the reduction of $\mathrm{NO}_{3}{ }^{-}$to highly oxidative $\mathrm{NO}_{2}$ and acts as reducing reagents for the subsequent chemical reduction of $\mathrm{NO}_{2}$ to $\mathrm{NO}_{2}{ }^{-}$, which is supported by the over $100 \% \mathrm{FE}$ for $\mathrm{NO}_{3} \mathrm{RR}$ at -0.025 and $-0.125 \mathrm{~V}$ (vs. RHE) (Supplementary Fig. S14c). This chemical step will lead to the partial oxidation of metallic $\mathrm{Cu}$ to $\mathrm{CuO}_{x}$ in alkaline electrolytes. According to recent DFT calculations on $\mathrm{Cu}$ and mixed $\mathrm{Cu} / \mathrm{Cu}_{2} \mathrm{O}$ phase, the latter was suggested to be more active for $\mathrm{NO}_{3}{ }^{-}$to $\mathrm{NO}_{2}{ }^{-}$conversion ${ }^{44}$. Therefore, at low overpotentials, the catalytic nature of CuSP for $\mathrm{NO}_{3} \mathrm{RR}$ is related to the $\mathrm{Cu} / \mathrm{CuO}_{x}$ phases, considering the XPS-evidenced presence of $\mathrm{Cu}^{0}$ phase.

On the CoSP catalysts, the characteristic Raman peaks of multiple $\mathrm{Co}^{3+}$-based phases and $\mathrm{Co}(\mathrm{OH})_{2}$ are fast attenuated with decreasing potentials from $0.025 \mathrm{~V}$ to $-0.325 \mathrm{~V}$ (Supplementary Fig. S30b) ${ }^{77-79}$. This indicates the gradual conversion of $\mathrm{Co}^{3+}$-based phases and $\mathrm{Co}(\mathrm{OH})_{2}$ into $\mathrm{CoO}$ and metallic $\mathrm{Co}$ in the absence of $\mathrm{NO}_{3}{ }^{-77}$. In $0.01 \mathrm{M} \mathrm{NO}_{3}{ }^{-}$the attenuation rate of these Raman peaks was much slower (Fig. 5b). Remarkably, the Raman signals associated with $\mathrm{CoOOH}$ and $\mathrm{Co}_{3} \mathrm{O}_{4}$ phases increase at 0.025 and $-0.025 \mathrm{~V}$, suggesting the partial oxidation of $\mathrm{Co}^{2+}$ in CoSP to $\mathrm{Co}^{3+77,78}$. Because of this, the electrolysis product of $\mathrm{NO}_{3}^{-}$at 0.025 and $-0.025 \mathrm{~V}$ should be only the highly oxidative $\mathrm{NO}_{2}$ species in Ar-saturated alkaline electrolytes $^{49}$, and their formation slows down the phase conversion. In this context, the $\mathrm{Co}^{2+}$-based phases act as chemical reducing reagents and offer additional electrons for reduction of $\mathrm{NO}_{2}$ to $\mathrm{NO}_{2}{ }^{-}$, after which the formed $\mathrm{NO}_{2}{ }^{-}$will be electrochemically reduced to $\mathrm{NH}_{3}$ as evidenced by the low overpotential of CoSP for the $\mathrm{NO}_{2}{ }^{-}$reduction (Fig. 3a), finally contributing to the apparently highest $\mathrm{FE}$ for $\mathrm{NH}_{3}$ at low overpotentials (Fig. 2b). At $<-0.025 \mathrm{~V}$, the Raman signals of $\mathrm{Co}^{3+}$-based phases and $\mathrm{Co}(\mathrm{OH})_{2}$ start to weaken. This result, together with the potential at $-1 \mathrm{~mA} \mathrm{~cm}^{-2}$ of CoSP catalysts for $\mathrm{NO}_{3}{ }^{-}$reduction $(-0.071 \mathrm{~V})$, suggests that the fast reduction of $\mathrm{NO}_{3}{ }^{-}$into $\mathrm{NO}_{2}^{-}$on CoSP requires the in-situ formation of metallic Co. By contrast, we found that the $\mathrm{Co}^{2+}$ in CoSP was 

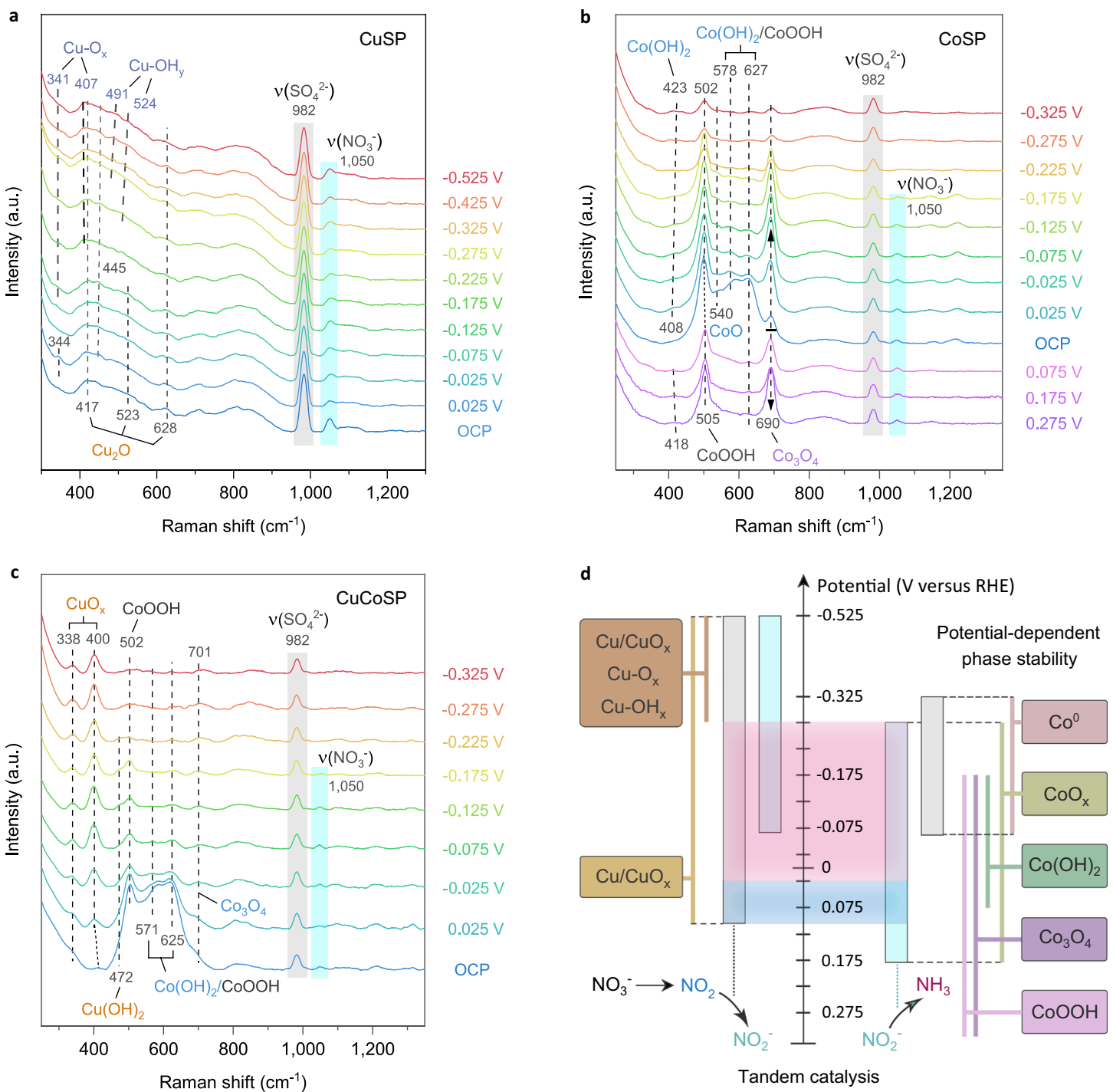

Fig. 5 In situ Raman spectra of the catalysts and schematic of the tandem mechanisms of CuCoSP catalysts. In situ Raman spectra of CuSP (a), CoSP (b) and $\mathrm{CuCoSP}$ (c) at different applied potentials in electrolytes containing $0.01 \mathrm{M} \mathrm{NO}_{3}{ }^{-}, 0.04 \mathrm{M} \mathrm{K}_{2} \mathrm{SO}_{4}$ and $0.01 \mathrm{M} \mathrm{KOH}$. d A proposed reaction mechanism of CuCoSP tandem catalysis of $\mathrm{NO}_{3} \mathrm{RR}$ at low overpotentials. In the middle of (d), the light blue region corresponds to the potential range for the reduction of $\mathrm{NO}_{3}-$ to $\mathrm{NO}_{2}$ species at the $\mathrm{Cu} / \mathrm{CuO}_{x}$ phases, resulting in the etching of catalysts, while the light pink region shows the potential range for efficient tandem reduction of $\mathrm{NO}_{3}-$ to $\mathrm{NH}_{3}$.

oxidized to $\mathrm{Co}^{3+}$ already at $>0.025 \mathrm{~V}^{77-79}$. Since the potential at $-1 \mathrm{~mA} \mathrm{~cm}^{-2}$ of CoSP for $\mathrm{NO}_{2}{ }^{-}$reduction is limited to $0.176 \mathrm{~V}$ (Fig. 3a), it can be concluded that the sharply increased $\mathrm{Co}^{3+}$. based phases at potentials $>0.025 \mathrm{~V}$ are inactive for $\mathrm{NO}_{2}{ }^{-}$ reduction. Thus, the active phase of CoSP for reducing $\mathrm{NO}_{3}-$ to $\mathrm{NO}_{2}{ }^{-}$is related to metallic $\mathrm{Co}$, while that for $\mathrm{NO}_{2}{ }^{-}$-to- $\mathrm{NH}_{3}$ conversion is a $\mathrm{Co}^{2+}$-dominated $\mathrm{CoO}_{x}$ phase.

For CuCoSP, the Raman peaks associated with Co-based phases were quickly attenuated with decreasing potentials, while a phase assigned to $\mathrm{CuO}_{\mathrm{x}}$ emerges at 338 and $400 \mathrm{~cm}^{-1}$ (Fig. $5 \mathrm{c}$ and Supplementary Fig. S30c) $)^{54}$. These results suggest an electrochemically driven phase separation in CuCoSP, leading to the formation of hybrid of $\mathrm{Cu} / \mathrm{CuO}_{\mathrm{x}}$ and $\mathrm{Co} / \mathrm{CoO}$ phases. The $\mathrm{CuO}_{x}$ persists to potentials as low as $-0.325 \mathrm{~V}$, further decreasing the probability of in situ surface $\mathrm{CuCo}$ alloying, especially at potentials $>-0.2 \mathrm{~V}$. This is further supported by the XRD patterns, HR-TEM and EDX-mapping images of CuCoSP after repeating three electrolysis cycles of one hour at $-0.325 \mathrm{~V}$ (Supplementary Fig. S4f and Fig. S24). The rate at which these Raman peaks are evolving is almost not impacted by the $\mathrm{NO}_{3} \mathrm{RR}$
(Fig. 5c and Supplementary Fig. S30c). This might be attributed to the high rate of $\mathrm{NO}_{3} \mathrm{RR}$ on $\mathrm{CuCoSP}$, which establishes a depletion layer of $\mathrm{NO}_{3}{ }^{-}$explaining the minor effects of the $\mathrm{NO}_{3} \mathrm{RR}$ on the phase-evolving rate. In stark contrast to CoSP (Fig. 5b), the Raman signals of $\mathrm{Co}^{3+}$-based phases in $\mathrm{CuCoSP}$ were not enhanced at both 0.025 and $-0.025 \mathrm{~V}$ in $0.01 \mathrm{M} \mathrm{NO}_{3}^{-}$. This finding indicates fast reduction of $\mathrm{NO}_{3}{ }^{-}$to $\mathrm{NO}_{2}{ }^{-}$rather than to oxidative $\mathrm{NO}_{2}$ species on the $\mathrm{Cu}$-based phases of CuCoSP. Accordingly, the active $\mathrm{Co}^{2+}$-based phases of $\mathrm{CuCoSP}$ are stabilized by the $\mathrm{Cu} / \mathrm{CuO}_{\mathrm{x}}$ phases, both of which are combined to form a tandem system for cascade $\mathrm{NO}_{3}{ }^{-}$-to- $\mathrm{NH}_{3}$ conversion at low overpotentials (Fig. 5d).

\section{Discussion}

In summary, we present a concept for designing efficient tandem catalysts, which involves the coupling of potential-dependent intermediate phases of transition metals to act as cooperative catalytic sites for cascade $\mathrm{NO}_{3}{ }^{-}$-to- $\mathrm{NH}_{3}$ conversion. This concept was verified using $\mathrm{Cu} / \mathrm{CuO}_{x}-\mathrm{Co} / \mathrm{CoO}$ hybrids with a well-defined 
spatial arrangement that is achieved by electrochemical redox activation-induced phase reconstruction of $\mathrm{Cu} / \mathrm{Co}$-based binary metal sulfides. In this tandem catalysis system, $\mathrm{NO}_{3}{ }^{-}$ions are reduced to $\mathrm{NO}_{2}{ }^{-}$preferentially on $\mathrm{Cu} / \mathrm{CuO}_{\mathrm{x}}$ phases, while the $\mathrm{NO}_{2}{ }^{-}$intermediates are then transferred and selectively converted to $\mathrm{NH}_{3}$ on $\mathrm{Co} / \mathrm{CoO}$ phases. The sequential $\mathrm{NO}_{3}{ }^{-}$and $\mathrm{NO}_{2}{ }^{-}$reduction on two different adjacent metal/metal oxide phases enables a high-rate $\mathrm{NH}_{3}$ generation at low overpotentials. At $-0.175 \mathrm{~V}$ vs. RHE, the designed CuCoSP catalysts show an excellent $\mathrm{FE}$ for $\mathrm{NH}_{3}$ (90.6\%) and super-high $\mathrm{Y}_{\mathrm{NH} 3}$ of $1.17 \mathrm{mmol} \mathrm{cm}^{-2} \mathrm{~h}^{-1}$ in $0.1 \mathrm{M} \mathrm{NO}_{3}{ }^{-}$at $\mathrm{pH} 13$, outperforming most of the $\mathrm{NO}_{3} \mathrm{RR}$ catalysts at the same conditions. Although tandem catalysis was widely employed in heterogeneous systems, this study provides a direct demonstration of efficiently using distinct potential-dependent intermediate phases as tandem catalytic sites. This concept of splicing active phases of transition metals represents a powerful strategy towards designing highperformance, multi-functional electrocatalysts for multi-step chemical reactions, such as e.g. urea electrosynthesis by integrating $\mathrm{NO}_{3} \mathrm{RR}$ with $\mathrm{CO}_{2}$ reduction.

\section{Methods}

Chemicals. $\mathrm{Na}_{2} \mathrm{HPO}_{4}(\geq 99.0 \%)$ and $\mathrm{NaClO}$ solution $(17 \%)$ were purchased from VWR. Maleic acid $(\geq 99.0 \%)$ was obtained from Riedel-de Haën. All other chemicals and $\mathrm{Cu}$ foil $(99.98 \%)$ were from Sigma-Aldrich. All chemicals were used without further purification. Carbon cloth was provided by PHYCHEMI.

Growth of ZIF-Co-R nanorods on $\mathrm{Cu}$ foil and carbon cloth. The $\mathrm{Cu}$ foil $(3 \times 0.5$ $\mathrm{cm}^{2}$ ) was washed with acetone, ethanol and distilled water, finally dried by blotting paper before use. The CC was initially treated with $1 \mathrm{M} \mathrm{HCl}(\geq 37 \%)$ for $12 \mathrm{~h}$, washed with deionized water and dried in a $70^{\circ} \mathrm{C}$ oven. Then, the CC was soaked in an aqueous solution of 2-methylimidazole ( $0.4 \mathrm{M}, 99 \%$ purity) for $12 \mathrm{~h}$ and dried by blotting paper before use. For the growth Co-ZIF-R nanorods, the $\mathrm{Cu}$ foil or CC was immersed into a $14 \mathrm{ml}$ growth solution, which was prepared by adding $10 \mathrm{ml}$ of 2-methylimidazole $(0.4 \mathrm{M})$ into $4 \mathrm{ml}$ aqueous solution of $\mathrm{Co}\left(\mathrm{NO}_{3}\right)_{2} 6 \mathrm{H}_{2} \mathrm{O}$ $(50 \mathrm{mM}, \geq 98 \%)$. The $\mathrm{Co}-\mathrm{ZIF}-\mathrm{R}$ nanorods were grown under static conditions at $25^{\circ} \mathrm{C}$ for $105 \mathrm{~min}$. The purple Co-ZIF-R nanorods on $\mathrm{Cu}$ foil or CC were washed with deionized water and dried in a $70^{\circ} \mathrm{C}$ oven.

EC-MOF for synthesis of CuCoSP_no. In a typical three-electrode system, the CoZIF-R on Cu foil was used as the working electrode, and $\mathrm{Ag} / \mathrm{AgCl}$ (sat. $\mathrm{KCl}$ ) and an FTO slide were employed as the reference and counter electrodes, respectively. In Ar-saturated electrolytes (aqueous solution of $0.5 \mathrm{M}$ thiourea ( $\geq 99.0 \%$ ), $0.25 \mathrm{M} \mathrm{KCl}$ $(\geq 99.0 \%)$ and $0.05 \mathrm{M} \mathrm{Na}_{2} \mathrm{HPO}_{4}$ ), the ZIF-Co-R was electrochemically converted via continuous $\mathrm{CV}$ scanning between $-1.76 \mathrm{~V}$ and $-0.15 \mathrm{~V}$ at a series of scan rates for different CV cycles (at $0.2 \mathrm{~V} \mathrm{~s}^{-1}$ for $1200 \mathrm{CV}$ cycles, at $0.1 \mathrm{~V} \mathrm{~s}^{-1}$ for $300 \mathrm{CV}$ cycles, at $0.05 \mathrm{~V} \mathrm{~s}^{-1}$ for $150 \mathrm{CV}$ cycles and finally at $0.02 \mathrm{~V} \mathrm{~s}^{-1}$ for $100 \mathrm{CV}$ cycles) using an Autolab potentiostat. The black products on $\mathrm{Cu}$ foil were taken out, rinsed with water and acetone, blow-dried by Ar gas and stored at $-21{ }^{\circ} \mathrm{C}$ for further characterization. Using the same method, the CuSP_no was prepared from $\mathrm{Cu}$ foil directly; the CoSP_no on CC was synthesized using ZIF-Co-R nanorods on CC as precursors; the CuCoS_no on $\mathrm{Cu}$ foil was obtained in an electrolyte with no $\mathrm{Na}_{2} \mathrm{HPO}_{4}$. As a control, metallic CuCo hybrids were prepared via electrodeposition of $\mathrm{CuCo}$ metals and alloy on CC in $0.05 \mathrm{M} \mathrm{H}_{2} \mathrm{SO}_{4}(98 \%)$ solution containing $4 \mathrm{mM}$ $\mathrm{CuSO}_{4}(\geq 99 \%)$ and $16 \mathrm{mM} \mathrm{CoSO}_{4}(\geq 99 \%)$ at $-1.75 \mathrm{~V}$ vs. $\mathrm{Ag} / \mathrm{AgCl}$ for $400 \mathrm{~s}$.

Electrochemical redox activation of the samples. Using a Gamry interface 1000 workstation, the samples were activated in $0.1 \mathrm{M} \mathrm{KOH}(\geq 85 \%)$ and $0.01 \mathrm{M}$ potassium nitrate $(\geq 99 \%)$ at $60 \mathrm{~mA} \mathrm{~cm}^{-2}$ for $45 \mathrm{~s}$. They then underwent continuous LSV sweeping at a rate of $20 \mathrm{mV} \mathrm{s}^{-1}$ from $-0.8 \mathrm{~V}$ to $-1.65 \mathrm{~V}$ (vs. Ag/ $\mathrm{AgCl})$ until the polarization curves reached a steady state. This activation process was repeated two or three times. Then, the samples were gently washed with water and acetone, and dried under Ar flow for further tests or characterizations. After the redox activation, the samples of CuCoSP_no, CuSP_no, CoSP_no and CuCoS_no were named as CuCoSP, CuSP, CoSP and CuCoS, respectively.

Material characterization. SEM was performed using a Quanta 3D FEG scanning electron microscope. TEM images, high-angle annular dark-field TEM images, SAED patterns, element mappings and EDX line-scan were carried out on a JEOL2800 TEM/STEM system using gold grids. XPS was recorded using an AXIS Nova spectrometer (Kratos Analytical) equipped with a monochromatic $\mathrm{Al} \mathrm{K \alpha} \mathrm{X}$-ray source ( $1487 \mathrm{eV}, 15 \mathrm{~mA}$ emission current) and an inert ion gas gun for depthprofiling composition analysis as a function of etching time. For the core-level spectra, the binding energies were calibrated based on the $\mathrm{C} 1 \mathrm{~s}$ feature located at
$284.8 \mathrm{eV}$. The nuclear magnetic resonance (NMR) spectroscopy was performed on a Bruker $400 \mathrm{MHz}$ NMR spectrometer. XRD were obtained using a Bruker D8 Discover X-ray diffractometer with $\mathrm{Cu}$ Ka radiation $(\lambda=1.5418 \AA)$.

Electrochemical $\mathbf{N O}_{3} \mathbf{R R}$ tests. The electrochemical tests were performed using a three-electrode system connected to the Gamry workstation in a typical H-type cell. The H-type cell was separated by a Nafion 117 membrane (Dupont) that was pretreated following reported procedures ${ }^{82}$. The catalysts were used as the working electrode, while $\mathrm{Ag} / \mathrm{AgCl}(3 \mathrm{M} \mathrm{KCl})$ and platinum mesh were used as the reference and counter electrodes, respectively. The electrolytes were Ar-saturated $0.1 \mathrm{M} \mathrm{KOH}$ ( $\mathrm{pH}$ 13) containing different concentrations of $\mathrm{NO}_{3}{ }^{-}$. The electrochemical cell was maintained in an Ar atmosphere during experiments. The LSV curves were collected at a scan rate of $5 \mathrm{mV} \mathrm{s}^{-1}$. All potentials were calibrated to the RHE reference scale using $E_{\mathrm{RHE}}=E_{\mathrm{Ag} / \mathrm{AgCl}}+0.207 \mathrm{~V}+0.0591 \times \mathrm{pH}$. The current density was normalized to the geometric electrode area $\left(\sim 0.5 \mathrm{~cm}^{2}\right)$. Note that the electrode area was $0.2 \mathrm{~cm}^{2}$ for tests in 0.05 and $0.1 \mathrm{M}$ nitrate. The solution resistance $\left(R_{\mathrm{S}}\right)$ was measured using potentiostatic electrochemical impedance spectroscopy with a frequency range of $0.1 \mathrm{~Hz}$ to $200 \mathrm{kHz}$ and an amplitude of $10 \mathrm{mV}_{\mathrm{pp}}$. The potentials were compensated by $\mathrm{iR}_{\mathrm{S}}$-drop from the electrolyte resistance. Potentiostatic measurements were performed for $1 \mathrm{~h}$ in $30 \mathrm{ml}$ cathode electrolyte with a stirring rate of $300 \mathrm{rpm}$, and then the electrolyte was stored at $4{ }^{\circ} \mathrm{C}$ (no more than 2 days) before analysis. To assess the performance change of $\mathrm{CuCoSP}$ during ten cycles of onehour electrolysis at $-0.175 \mathrm{~V}$ (vs. RHE), the electrolyte $(30 \mathrm{ml}, 0.1 \mathrm{M} \mathrm{KOH}$ and $0.01 \mathrm{M}$ nitrate) was collected after each one-hour electrolysis for product analysis and a fresh electrolyte was used for the next cycle of one-hour electrolysis. Note that $\mathrm{NH}_{3}$ volatilization in the electrolytes $(\mathrm{pH} 13)$ is negligible during the one-hour electrolysis (Supplementary Fig. S19). The $\mathrm{C}_{\mathrm{dl}}$ was determined by CV scanning in a non-faradaic potential window at different scan rates $\left(10-120 \mathrm{mV} \mathrm{s}^{-1}\right)$. The plot of capacitive anode and cathode current differences $\left[\left(j_{\mathrm{a}}-j_{\mathrm{c}}\right) / 2\right]$ at a set potential against the CV scan rates shows a linear relationship, and the slope is $\mathrm{C}_{\mathrm{dl}}$.

Kinetic evaluation. The LSVs of the catalysts were recorded at a scan rate of $1 \mathrm{mV} \mathrm{s}^{-1}$ in $0.1 \mathrm{M} \mathrm{KOH} \mathrm{(pH} \mathrm{13)} \mathrm{containing} 0.01 \mathrm{M} \mathrm{NO}_{3}^{-}$or $0.01 \mathrm{M} \mathrm{NO}_{2}^{-}$ $\left(\mathrm{KNO}_{2}, \geq 96 \%\right)$. To obtain the rate constant, the electrolysis at $-0.175 \mathrm{~V}$ (vs. RHE) were performed for $1 \mathrm{~h}$ in $22 \mathrm{ml}$ electrolyte $(0.1 \mathrm{M} \mathrm{KOH})$ containing $0.01 \mathrm{M} \mathrm{NO}_{3}$ or $0.01 \mathrm{M} \mathrm{NO}_{2}{ }^{-}$in the cathode chamber. The reaction constant $\left(\mathrm{k}_{1}\right.$ for $\mathrm{NO}_{3}$ reduction and $\mathrm{k}_{2}$ for $\mathrm{NO}_{2}{ }^{-}$reduction) was obtained by monitoring the concentration evolution of $\mathrm{NO}_{3}{ }^{-}$or $\mathrm{NO}_{2}{ }^{-}$ions as a function of electrolysis time, assuming that their concentrations decayed exponentially as per first-order rate, that is, $C_{\mathrm{t}}=C_{0} \exp (-k \times t)$, where, $C_{0}$ is the initial molar concentration of reactant $\left(\mathrm{NO}_{3}{ }^{-}\right.$or $\left.\mathrm{NO}_{2}{ }^{-}\right)$and $C_{\mathrm{t}}$ is the molar concentration of reactant at time $t$.

\section{Determination of ion concentrations}

$\mathrm{NH}_{4}^{+}$quantification. The produced $\mathrm{NH}_{3}$ was quantitatively determined using the indophenol blue method ${ }^{10,69}$. Typically, a certain amount of electrolyte was taken out from the reaction cell and diluted to $2 \mathrm{ml}$. Then, $2 \mathrm{ml}$ of $1 \mathrm{M} \mathrm{NaOH} \mathrm{( \geq 98 \% )}$ solution containing sodium citrate $(\geq 99 \%)$ and salicylic acid $(\geq 99 \%)$ (stored at $4{ }^{\circ} \mathrm{C}$ ) and $1 \mathrm{ml}$ of freshly prepared $0.05 \mathrm{M} \mathrm{NaClO}$ was added. The mixed solution was shaken for few seconds. Finally, $0.2 \mathrm{ml}$ of $1 \mathrm{wt} . \%$ sodium nitroferricyanide $(\geq 99 \%)$ solution (stored at $4{ }^{\circ} \mathrm{C}$ ) were added for the colour reaction. After keeping at room temperature for $1 \mathrm{~h}$, the resulting solution was measured using an ultraviolet-visible (UV-Vis) spectrophotometer. The absorbance at $\sim 655 \mathrm{~nm}$ was used to determine the concentration of $\mathrm{NH}_{3}$. In order to quantify the amount of $\mathrm{NH}_{3}$, a calibration curve was built using standard $\mathrm{NH}_{4} \mathrm{Cl}(\geq 99.5 \%)$ solution in $0.1 \mathrm{M} \mathrm{KOH}$.

$\mathrm{NO}_{2}{ }^{-}$quantification ${ }^{44}$. A specific colour reagent for $\mathrm{NO}_{2}{ }^{-}$quantification was prepared by mixing $0.20 \mathrm{~g}$ of $\mathrm{N}$-(1-naphthyl) ethylenediamine dihydrochloride $(\geq 98 \%)$, $4.0 \mathrm{~g}$ of sulfonamide $(\geq 99 \%)$ and $10 \mathrm{ml}$ of phosphoric acid $\left(85 \mathrm{wt} . \%\right.$ in $\mathrm{H}_{2} \mathrm{O}$ ) $(\rho=1.7 \mathrm{~g} / \mathrm{ml})$ with $50 \mathrm{ml}$ of deionized water. In a typical colourimetric test, $1 \mathrm{ml}$ $\mathrm{HCl}(1 \mathrm{M})$ was firstly added into the $5 \mathrm{ml}$ of diluted post-electrolysis electrolytes, and then $0.1 \mathrm{ml}$ of colour reagent was added and shaken to obtain a uniform solution. The UV-Vis absorbance at $540 \mathrm{~nm}$ was recorded after $20 \mathrm{~min}$ at room temperature. The amount of $\mathrm{NO}_{2}{ }^{-}$was determined using a calibration curve of $\mathrm{NaNO}_{2}(\geq 96 \%)$ solutions. $\mathrm{N}_{2} \mathrm{H}_{4}$ and $\mathrm{NH}_{2} \mathrm{OH}$ were probably produced during the electroreduction of nitrate. However, their concentrations are expected to be very low and only measurable at intermediate times, owing to their high reactivity in basic media ${ }^{42,43}$. Thus, we mainly focused on analyzing the yields of $\mathrm{NH}_{3}$ and $\mathrm{NO}_{2}{ }^{-}$.

$\mathrm{NO}_{3}{ }^{-}$quantification ${ }^{44,83}$. A certain amount of post-electrolysis electrolytes was diluted to $4 \mathrm{ml}$. Then, $1 \mathrm{ml}$ of $1 \mathrm{M} \mathrm{HCl}$ and $0.1 \mathrm{ml}$ sulfamic acid $(98 \%)$ solution $(0.8 \mathrm{wt} . \%)$ were added, and the final mixed solution was shaken to obtain a uniform solution. UV-Vis spectrophotometer was used to record the absorption intensities at wavelengths of $220 \mathrm{~nm}$ and $275 \mathrm{~nm}$. The calculated absorbance value A $\left(A=A_{220 \mathrm{~nm}}-2 \times A_{275 \mathrm{~nm}}\right)$ is linearly related to the $\mathrm{NO}_{3}{ }^{-}$concentrations. In order to quantify the amount of $\mathrm{NO}_{3}{ }^{-}$, a calibration curve was obtained using $\mathrm{KNO}_{3}$ standard solution.

Calculation of the $\mathbf{F E}, \mathbf{Y}_{\mathbf{N H 3}}$ and $\boldsymbol{j}_{\mathbf{N H 3}}$. The $\mathrm{FE}$ was defined as the charge consumed for the formation of a specific product (e.g., $\mathrm{NH}_{3}$ ) divided by the total charge passing 
through the electrodes $(\mathrm{Q})$ during electrolysis. Given that eight electrons are consumed to produce one $\mathrm{NH}_{3}$ molecule, the $\mathrm{FE}$ of $\mathrm{NH}_{3}\left(\mathrm{FE}_{\mathrm{NH}}\right), \mathrm{Y}_{\mathrm{NH}}$ and $j_{\mathrm{NH}}$ can be calculated as follows: $\mathrm{FE}_{\mathrm{NH} 3}=\left(8 \times \mathrm{F} \times C_{\mathrm{NH} 3} \times V\right) / \mathrm{Q}, \mathrm{Y}_{\mathrm{NH} 3}=\left(C_{\mathrm{NH} 3} \times V\right) /(A \times t)$, and $j_{\mathrm{NH} 3}=\left(Q \times F E_{\mathrm{NH} 3}\right) /(A \times t)$, where $F$ is the Faraday constant, $C_{\mathrm{NH} 3}$ is the molar concentration of detected $\mathrm{NH}_{3}, \mathrm{~V}$ is the volume of the electrolytes, $A$ is the electrode geometric area, and $t$ is the reaction time. Given that two electrons are consumed to produce one $\mathrm{NO}_{2}^{-}$molecule, the $\mathrm{FE}$ of $\mathrm{NO}_{2}{ }^{-}$can be calculated as follows: $\mathrm{FE}\left(\mathrm{NO}_{2}^{-}\right)=$ $\left(2 \times \mathrm{F} \times C\left(\mathrm{NO}_{2}^{-}\right) \times V\right) / \mathrm{Q}$, where $C\left(\mathrm{NO}_{2}^{-}\right)$is the molar concentration of detected $\mathrm{NO}_{2}^{-}$.

${ }^{15} \mathrm{NO}_{3}{ }^{-}$Isotope labelling experiments and ${ }^{14} \mathrm{NH}_{3}$ quantification by ${ }^{1} \mathrm{H}$ NMR. To quantify the ${ }^{14} \mathrm{NH}_{4}{ }^{+}$yield after electrolysis of $0.01 \mathrm{M} \mathrm{K}^{14} \mathrm{NO}_{3}$ at $-0.175 \mathrm{~V}$ (vs. RHE) for $1 \mathrm{~h}$, a calibration curve of ${ }^{1} \mathrm{H}$ NMR $(400 \mathrm{MHz})$ measurements was constructed using a series of ${ }^{14} \mathrm{NH}_{4} \mathrm{Cl}$ solutions with defined concentrations (1, 2, 3,4 and $5 \mathrm{mM}$ ) as standards. In a typical procedure ${ }^{84}, 125 \mu$ lof the standard solution/electrolytes was mixed with $125 \mu \mathrm{l}$ of $15 \mathrm{mM}$ maleic acid in DMSO- $\mathrm{D}_{6}$ (99.9 atom\% D), $50 \mu \mathrm{l}$ of $4 \mathrm{M} \mathrm{H}_{2} \mathrm{SO}_{4}$ in DMSO- $\mathrm{D}_{6}$ and $750 \mu \mathrm{l}$ of DMSO- $\mathrm{D}_{6}$. The peak area integral ratio of ${ }^{14} \mathrm{NH}_{4}{ }^{+}$to maleic acid is positively correlated with the concentrations of ${ }^{14} \mathrm{NH}_{4}{ }^{+}$. To confirm the source of $\mathrm{NH}_{3}$ qualitatively, $0.01 \mathrm{M}$ $\mathrm{Na}^{15} \mathrm{NO}_{3}\left(>98\right.$ atom $\%{ }^{15} \mathrm{~N}, \geq 99 \%$ purity) and $0.1 \mathrm{M} \mathrm{KOH}$ were used as the feeding electrolytes for $1 \mathrm{~h}$ electrolysis at $-0.175 \mathrm{~V}$ (vs. RHE) and ${ }^{15} \mathrm{NH}_{4}{ }^{+}$in the electrolyte was detected using ${ }^{1} \mathrm{H} \mathrm{NMR}^{84}$.

Operando SECM test. To prepare the model catalyst, a CuSP slid $\left(0.5 \times 3 \mathrm{~cm}^{2}\right)$ was cleaned using $0.1 \mathrm{M} \mathrm{HCl}$ under ultrasonication for $20 \mathrm{~min}$, washed by deionized water, and dried by blotting paper. Then, half of the CuSP slid was immersed in a MOFs growth solution (a mixture of $1.5 \mathrm{ml}$ of 2-methylimidazole $(0.4 \mathrm{M})$ and $1.5 \mathrm{ml}$ aqueous solution of $\left.\mathrm{Co}\left(\mathrm{NO}_{3}\right)_{2} 6 \mathrm{H}_{2} \mathrm{O}(50 \mathrm{mM})\right)$ in Ar-atmosphere for $6 \mathrm{~h}$. The formed Cu_ZIF-Co hybrid layers were washed with deionized water, dried with blotting paper, and further immersed in $1 \mathrm{M} \mathrm{KOH}$ solution bubbled with Ar gas for $1.5 \mathrm{~h}$ in a gas-tight cell, during which the ZIF-Co film was completely converted into a uniform and compacted $\mathrm{Co}(\mathrm{OH})_{2}$ layer, due to the poor stability of ZIF-Co MOFs in water ${ }^{85}$. After washed with water and ethanol and drying at $25^{\circ} \mathrm{C}$, half of the $\mathrm{CuSP}$ slide was exposed in Air and the other half was covered by $\mathrm{Co}(\mathrm{OH})_{2}$ nanosheets, both of which constitute the $\mathrm{Cu}\left(\mathrm{CuO}_{\mathrm{x}}\right)_{2} \mathrm{Co}(\mathrm{OH})_{2}$ model catalyst.

The SECM setup with shear-force-based distance control is located in a faraday cage to allow for shielding of electrical noise, with the exception of the lock-in amplifier and the potentiostat ${ }^{86,87}$. During the SECM measurements, the $\mathrm{Cu} \_\mathrm{Co}(\mathrm{OH})_{2}$ catalyst were used as the sample (working electrode 1 ; WE 1 ), while a $\mathrm{Pt}-\mathrm{UME}$ with a diameter of $\sim 1 \mu \mathrm{m}$ (working electrode 2 ; WE 2 ), $\mathrm{Ag} / \mathrm{AgCl} / 3 \mathrm{M} \mathrm{KCl}$ (reference electrode) and a Pt-mesh (counter electrode separated by a Zirfon membrane) were assembled to a four-electrode system. The sample was polarized to $-0.12 \mathrm{~V}$ (vs. RHE) for triggering the $\mathrm{NO}_{3} \mathrm{RR}$, while at the Pt-UME cyclic voltammograms were performed in a potential range between $-0.12 \mathrm{~V}$ and $1.58 \mathrm{~V}$ (vs. RHE) at a scan rate of $200 \mathrm{mV} \mathrm{s}^{-1}$ to identify intermediately formed $\mathrm{NO}_{2}{ }^{-}$(at $0.06 \mathrm{~V}$ vs. RHE) and $\mathrm{NH}_{3}$ (at $0.76 \mathrm{~V}$ vs. RHE). Each SECM array scan was recorded from the $\mathrm{Cu} / \mathrm{CuO}_{x}$ layer to the $\mathrm{Co}(\mathrm{OH})_{2}$ layer with an overall $\mathrm{x}$-displacement of $1200 \mu \mathrm{m}$, while the border between the two layers is at $\sim 600 \mu \mathrm{m}$.

In situ Raman spectroscopy. Raman spectroscopy was performed with a Lab -RAM HR Raman microscopy system (Horiba Jobin Yvon, HR550) equipped with a $532 \mathrm{~nm}$ laser as the excitation source, a water immersion objective (Olympus LUMFL, $60 \times$, numerical aperture $=1.10)$, a monochromator $(1800$ grooves $/ \mathrm{mm}$ grating) and a Synapse CCD detector. Each spectrum is an average of five continuously acquired spectra with a collection time of $50 \mathrm{~s}$ each. A three-electrode electrochemical cell was used for in situ Raman tests. Pt wires and $\mathrm{Ag} / \mathrm{AgCl}(3 \mathrm{M}$ $\mathrm{KCl}$ ) were used as counter and reference electrodes, respectively. To protect the objective from the corrosive $0.1 \mathrm{M} \mathrm{KOH}$ electrolyte, $0.01 \mathrm{M} \mathrm{KOH}$ (pH 12) was used instead. $\mathrm{K}_{2} \mathrm{SO}_{4}(\geq 99.0 \%)$ was added to ensure sufficient ionic conductivity (keeping the total concentration of $\mathrm{K}^{+}$to be $0.1 \mathrm{M}$ ) and provides $\mathrm{SO}_{4}{ }^{2-}$ ions as an external Raman reference. Typically, in the presence of $0.01 \mathrm{M} \mathrm{KNO}_{3}$, the supporting electrolytes were $0.01 \mathrm{M} \mathrm{KOH}$ and $0.04 \mathrm{M} \mathrm{K}_{2} \mathrm{SO}_{4}$. In the absence of $\mathrm{KNO}_{3}$, the electrolytes were $0.01 \mathrm{M} \mathrm{KOH}$ and $0.045 \mathrm{M} \mathrm{K}_{2} \mathrm{SO}_{4}$.

\section{Data availability}

The data generated and analyzed during this study are provided in the main text and Supplementary information file or can be obtained from the corresponding authors on reasonable request.

Received: 28 August 2021; Accepted: 8 February 2022;

Published online: 02 March 2022

\section{References}

1. Foster, S. L. et al. Catalysts for nitrogen reduction to ammonia. Nat. Catal. 1, 490-500 (2018).
2. Ashida, Y., Arashiba, K., Nakajima, K. \& Nishibayashi, Y. Molybdenum catalysed ammonia production with samarium diiodide and alcohols or water. Nature 568, 536-540 (2019).

3. Tang, C. \& Qiao, S. -Z. How to explore ambient electrocatalytic nitrogen reduction reliably and insightfully. Chem. Soc. Rev. 48, 3166-3180 (2019).

4. Kitano, M. et al. Ammonia synthesis using a stable electride as an electron donor and reversible hydrogen store. Nat. Chem. 4, 934-940 (2012).

5. Martín, A. J., Shinagawa, T. \& Pérez-Ramírez, J. Electrocatalytic reduction of nitrogen: From Haber-Bosch to ammonia artificial leaf. Chem 5, 263-283 (2019).

6. Guo, C., Ran, J., Vasileff, A. \& Qiao, S. -Z. Rational design of electrocatalysts and photo(electro)catalysts for nitrogen reduction to ammonia $\left(\mathrm{NH}_{3}\right)$ under ambient conditions. Energy Environ. Sci. 11, 45-56 (2018).

7. Soloveichik, G. Electrochemical synthesis of ammonia as a potential alternative to the Haber-Bosch process. Nat. Catal. 2, 377-380 (2019).

8. Wan, Y., Xu, J. \& Lv, R. Heterogeneous electrocatalysts design for nitrogen reduction reaction under ambient conditions. Mater. Today 27, 69-90 (2019)

9. Cui, X., Tang, C. \& Zhang, Q. A review of electrocatalytic reduction of dinitrogen to ammonia under ambient conditions. Adv. Energy Mater. 8, 1800369 (2018)

10. Wang, J. et al. Ambient ammonia synthesis via palladium-catalyzed electrohydrogenation of dinitrogen at low overpotential. Nat. Commun. 9, 1795 (2018).

11. Chen, P. et al. Interfacial engineering of cobalt sulfide/graphene hybrids for highly efficient ammonia electrosynthesis. Proc. Natl Acad. Sci. USA 116, 6635-6640 (2019).

12. Song, Y. et al. A physical catalyst for the electrolysis of nitrogen to ammonia Sci. Adv. 4, e1700336 (2018).

13. Lv, C. et al. An amorphous noble-metal-free electrocatalyst that enables nitrogen fixation under ambient conditions. Angew. Chem. Int. Ed. 57, 6073-6076 (2018)

14. Li, S. -J. et al. Amorphizing of Au Nanoparticles by CeOx-RGO hybrid support towards highly efficient electrocatalyst for $\mathrm{N}_{2}$ reduction under ambient conditions. Adv. Mater. 29, 1700001 (2017).

15. Geng, Z. et al. Achieving a record-high yield rate of $120.9 \mu \mathrm{g}_{\mathrm{NH} 3} \mathrm{mg}_{\text {cat. }}{ }^{-1} \mathrm{~h}^{-1}$ for $\mathrm{N}_{2}$ electrochemical reduction over $\mathrm{Ru}$ single-atom catalysts. Adv. Mater. 30, 1803498 (2018).

16. Chen, G. -F. et al. Ammonia electrosynthesis with high selectivity under ambient conditions via a $\mathrm{Li}^{+}$incorporation strategy. J. Am. Chem. Soc. 139, 9771-9774 (2017)

17. Rosca, V., Duca, M., de Groot, M. T. \& Koper, M. T. M. Nitrogen cycle electrocatalysis. Chem. Rev. 109, 2209-2244 (2009).

18. Chen, J. G. et al. Beyond fossil fuel-driven nitrogen transformations. Science 360, eaar6611 (2018).

19. Long, J. et al. Direct electrochemical ammonia synthesis from nitric oxide. Angew. Chem. Int. Ed. 59, 9711-9718 (2020).

20. Wang, Y., Yu, Y., Jia, R., Zhang, C. \& Zhang, B. Electrochemical synthesis of nitric acid from air and ammonia through waste utilization. Natl Sci. Rev. 6, 730-738 (2019).

21. van Langevelde, P. H., Katsounaros, I. \& Koper, M. T. M. Electrocatalytic nitrate reduction for sustainable ammonia production. Joule 5, 290-294 (2021).

22. McEnaney, J. M. et al. Electrolyte engineering for efficient electrochemical nitrate reduction to ammonia on a titanium electrode. ACS Sustain. Chem. Eng. 8, 2672-2681 (2020).

23. Hao, D. et al. Emerging alternative for artificial ammonia synthesis through catalytic nitrate reduction. J. Mater. Res. Technol. 77, 163-168 (2021).

24. Katsounaros, I. On the assessment of electrocatalysts for nitrate reduction Curr. Opin. Electrochem. 28, 100721 (2021)

25. $\mathrm{Wu}, \mathrm{Z}$. - Y. et al. Electrochemical ammonia synthesis via nitrate reduction on Fe single atom catalyst. Nat. Commun. 12, 2870 (2021).

26. Yu, Y., Wang, C., Yu, Y., Wang, Y. \& Zhang, B. Promoting selective electroreduction of nitrates to ammonia over electron-deficient Co modulated by rectifying Schottky contacts. Sci. China Chem. 63, 1469-1476 (2020).

27. Sun, J. et al. A hybrid plasma electrocatalytic process for sustainable ammonia production. Energy Environ. Sci. 14, 865-872 (2021)

28. Li, L. et al. Efficient nitrogen fixation to ammonia through integration of plasma oxidation with electrocatalytic reduction. Angew. Chem. Int. Ed. 60, 14131-14137 (2021).

29. Milton, R. D. \& Minteer, S. D. Enzymatic bioelectrosynthetic ammonia production: recent electrochemistry of nitrogenase, nitrate reductase, and nitrite reductase. ChemPlusChem 82, 513-521 (2017).

30. Duca, M., Weeks, J. R., Fedor, J. G., Weiner, J. H. \& Vincent, K. A. Combining noble metals and enzymes for relay cascade electrocatalysis of nitrate reduction to ammonia at neutral pH. ChemElectroChem 2, 1086-1089 (2015)

31. Ford, C. L., Park, Y. J., Matson, E. M., Gordon, Z. \& Fout, A. R. A bioinspired iron catalyst for nitrate and perchlorate reduction. Science 354, 741-743 (2016). 
32. Coelho, C. \& Romão, M. J. Structural and mechanistic insights on nitrate reductases. Protein Sci. 24, 1901-1911 (2015).

33. Harris, L. E. The lower electronic states of nitrite and nitrate ion, nitromethane, nitramide, nitric acid, and nitrate esters. J. Chem. Phys. 58 5615-5626 (1973).

34. Li, Y. et al. Enzyme mimetic active intermediates for nitrate reduction in neutral aqueous media. Angew. Chem. Int. Ed. 59, 9744-9750 (2020).

35. Wang, Z., Richards, D. \& Singh, N. Recent discoveries in the reaction mechanism of heterogeneous electrocatalytic nitrate reduction. Catal. Sci. Technol. 11, 705-725 (2021).

36. Duca, M. \& Koper, M. T. M. Powering denitrification: the perspectives of electrocatalytic nitrate reduction. Energy Environ. Sci. 5, 9726-9742 (2012).

37. Liu, J. -X., Richards, D., Singh, N. \& Goldsmith, B. R. Activity and selectivity trends in electrocatalytic nitrate reduction on transition metals. ACS Catal. $\mathbf{9}$, 7052-7064 (2019).

38. Wang, S. et al. Universal transition state scaling relations for (de) hydrogenation over transition metals. Phys. Chem. Chem. Phys. 13, 20760-20765 (2011).

39. $\mathrm{Li}, \mathrm{F}$. et al. Cooperative $\mathrm{CO}_{2}$-to-ethanol conversion via enriched intermediates at molecule-metal catalyst interfaces. Nat. Catal. 3, 75-82 (2020).

40. Martinez, J., Ortiz, A. \& Ortiz, I. State-of-the-art and perspectives of the catalytic and electrocatalytic reduction of aqueous nitrates. Appl. Catal. B: Environ. 207, 42-59 (2017).

41. Zhang, X. et al. Recent advances in non-noble metal electrocatalysts for nitrate reduction. Chem. Eng. J. 403, 126269 (2021).

42. Pérez-Gallent, E., Figueiredo, M. C., Katsounaros, I. \& Koper, M. T. M. Electrocatalytic reduction of nitrate on copper single crystals in acidic and alkaline solutions. Electrochim. Acta 227, 77-84 (2017).

43. Reyter, D., Bélanger, D. \& Roué, L. Study of the electroreduction of nitrate on copper in alkaline solution. Electrochim. Acta 53, 5977-5984 (2008).

44. Wang, Y., Zhou, W., Jia, R., Yu, Y. \& Zhang, B. Unveiling the activity origin of a copper-based electrocatalyst for selective nitrate reduction to ammonia. Angew. Chem. Int. Ed. 59, 5350-5354 (2020).

45. Wang, Y. et al. Enhanced nitrate-to-ammonia activity on copper-nickel alloys via tuning of intermediate adsorption. J. Am. Chem. Soc. 142, 5702-5708 (2020).

46. Lu, C., Lu, S., Qiu, W. \& Liu, Q. Electroreduction of nitrate to ammonia in alkaline solutions using hydrogen storage alloy cathodes. Electrochim. Acta 44, 2193-2197 (1999).

47. Durivault, $\mathrm{L}$. et al. $\mathrm{Cu}-\mathrm{Ni}$ materials prepared by mechanical milling: their properties and electrocatalytic activity towards nitrate reduction in alkaline medium. J. Alloy. Compd. 432, 323-332 (2007).

48. Dima, G. E., de Vooys, A. C. A. \& Koper, M. T. M. Electrocatalytic reduction of nitrate at low concentration on coinage and transition-metal electrodes in acid solutions. J. Electroanal. Chem. 554-555, 15-23 (2003).

49. Su, J. F., Ruzybayev, I., Shah, I. \& Huang, C. P. The electrochemical reduction of nitrate over micro-architectured metal electrodes with stainless steel scaffold. Appl. Catal. B: Environ. 180, 199-209 (2016).

50. Reyter, D., Chamoulaud, G., Bélanger, D. \& Roué, L. Electrocatalytic reduction of nitrate on copper electrodes prepared by high-energy ball milling. $J$. Electroanal. Chem. 596, 13-24 (2006).

51. Chen, G. -F. et al. Electrochemical reduction of nitrate to ammonia via direct eight-electron transfer using a copper-molecular solid catalyst. Nat. Energy 5 , 605-613 (2020).

52. Li, J. et al. Efficient ammonia electrosynthesis from nitrate on strained ruthenium nanoclusters. J. Am. Chem. Soc. 142, 7036-7046 (2020).

53. Zhao, Y. et al. Speciation of $\mathrm{Cu}$ surfaces during the electrochemical $\mathrm{CO}$ reduction reaction. J. Am. Chem. Soc. 142, 9735-9743 (2020).

54. Deng, Y., Handoko, A. D., Du, Y., Xi, S. \& Yeo, B. S. In situ Raman spectroscopy of copper and copper oxide surfaces during electrochemical oxygen evolution reaction: identification of $\mathrm{Cu}^{\mathrm{III}}$ oxides as catalytically active species. ACS Catal. 6, 2473-2481 (2016).

55. Wang, L. et al. Migration of cobalt species within mixed platinum-cobalt oxide bifunctional electrocatalysts in alkaline electrolytes. J. Electrochem. Soc. 166, F3093-F3097 (2019).

56. Zheng, W., Liu, M. \& Lee, L. Y. S. Electrochemical instability of metal-organic frameworks: In situ spectroelectrochemical investigation of the real active Sites. ACS Catal. 10, 81-92 (2020).

57. Mefford, J. T. et al. Correlative operando microscopy of oxygen evolution electrocatalysts. Nature 593, 67-73 (2021).

58. Wang, J., Tan, H. -Y., Zhu, Y., Chu, H. \& Chen, H. M. Linking the dynamic chemical state of catalysts with the product profile of electrocatalytic $\mathrm{CO}_{2}$ reduction. Angew. Chem. Int. Ed. 60, 17254-17267 (2021).

59. Morales-Guio, C. G. et al. Improved $\mathrm{CO}_{2}$ reduction activity towards $\mathrm{C}_{2+}$ alcohols on a tandem gold on copper electrocatalyst. Nat. Catal. 1, 764-771 (2018).

60. Yan, $\mathrm{H}$. et al. Tandem $\operatorname{In}_{2} \mathrm{O}_{3}-\mathrm{Pt} / \mathrm{Al}_{2} \mathrm{O}_{3}$ catalyst for coupling of propane dehydrogenation to selective $\mathrm{H}_{2}$ combustion. Science 371, 1257-1260 (2021).
61. Yamada, Y. et al. Nanocrystal bilayer for tandem catalysis. Nat. Chem. 3, 372-376 (2011)

62. O’Mara, P. B. et al. Cascade reactions in nanozymes: spatially separated active sites inside Ag-core-porous-Cu-shell nanoparticles for multistep carbon dioxide reduction to higher organic molecules. J. Am. Chem. Soc. 141, 14093-14097 (2019).

63. Fajardo, A. S., Westerhoff, P., Sanchez-Sanchez, C. M. \& Garcia-Segura, S. Earth-abundant elements a sustainable solution for electrocatalytic reduction of nitrate. Appl. Catal. B: Environ. 281, 119465 (2021).

64. Guo, Y., Stroka, J. R., Kandemir, B., Dickerson, C. E. \& Bren, K. L. Cobalt metallopeptide electrocatalyst for the selective reduction of nitrite to ammonium. J. Am. Chem. Soc. 140, 16888-16892 (2018).

65. He, W., Ifraemov, R., Raslin, A. \& Hod, I. Room-temperature electrochemical conversion of metal-organic frameworks into porous amorphous metal sulfides with tailored composition and hydrogen evolution activity. Adv. Funct. Mater. 28, 1707244 (2018).

66. He, W., Liberman, I., Rozenberg, I., Ifraemov, R. \& Hod, I. electrochemically driven cation exchange enables the rational design of active $\mathrm{CO}_{2}$ reduction electrocatalysts. Angew. Chem. Int. Ed. 59, 8262-8269 (2020).

67. Liberman, I., He, W., Shimoni, R., Ifraemov, R. \& Hod, I. Spatially confined electrochemical conversion of metal-organic frameworks into metal-sulfides and their in situ electrocatalytic investigation via scanning electrochemical microscopy. Chem. Sci. 11, 180-185 (2020).

68. Choi, J. et al. Identification and elimination of false positives in electrochemical nitrogen reduction studies. Nat. Commun. 11, 5546 (2020).

69. Zhao, Y. et al. Ammonia detection methods in photocatalytic and electrocatalytic experiments: How to improve the reliability of $\mathrm{NH}_{3}$ production rates? Adv. Sci. 6, 1802109 (2019).

70. Lefebvre, M. C. In Modern Aspects of Electrochemistry (eds Conway, B. E. et al.) 249-300 (Springer USA, 2002).

71. Fang, Y. -H. \& Liu, Z. -P. Tafel kinetics of electrocatalytic reactions: from experiment to first-principles. ACS Catal. 4, 4364-4376 (2014).

72. Petrii, O. A., Nazmutdinov, R. R., Bronshtein, M. D. \& Tsirlina, G. A. Life of the tafel equation: Current understanding and prospects for the second century. Electrochim. Acta 52, 3493-3504 (2007).

73. Kim, H. et al. Operando stability of platinum electrocatalysts in ammonia oxidation reactions. ACS Catal. 10, 11674-11684 (2020).

74. Duca, M. et al. New insights into the mechanism of nitrite reduction on a platinum electrode. J. Electroanal. Chem. 649, 59-68 (2010).

75. Yang, J., Sebastian, P., Duca, M., Hoogenboom, T. \& Koper, M. T. M. pH dependence of the electroreduction of nitrate on Rh and Pt polycrystalline electrodes. Chem. Commun. 50, 2148-2151 (2014).

76. Krylova, V. \& Andrulevičius, M. Optical, XPS and XRD studies of semiconducting copper sulfide layers on a polyamide film. Int. J. Photoenergy 2009, 304308 (2009).

77. Rivas-Murias, B. \& Salgueiriño, V. Thermodynamic $\mathrm{CoO}-\mathrm{Co}_{3} \mathrm{O}_{4}$ crossover using Raman spectroscopy in magnetic octahedron-shaped nanocrystals. J. Raman Spectrosc. 48, 837-841 (2017).

78. Yang, J., Liu, H., Martens, W. N. \& Frost, R. L. Synthesis and characterization of cobalt hydroxide, cobalt oxyhydroxide, and cobalt oxide nanodiscs. J. Phys. Chem. C. 114, 111-119 (2010).

79. Liu, Y. -C., Koza, J. A. \& Switzer, J. A. Conversion of electrodeposited $\mathrm{Co}(\mathrm{OH})_{2}$ to $\mathrm{CoOOH}$ and $\mathrm{Co}_{3} \mathrm{O}_{4}$, and comparison of their catalytic activity for the oxygen evolution reaction. Electrochim. Acta 140, 359-365 (2014).

80. Dupin, J. -C., Gonbeau, D., Vinatier, P. \& Levasseur, A. Systematic XPS studies of metal oxides, hydroxides and peroxides. Phys. Chem. Chem. Phys. 2, 1319-1324 (2000)

81. Xu, M., Larentzos, J. P., Roshdy, M., Criscenti, L. J. \& Allen, H. C. Aqueous divalent metal-nitrate interactions: hydration versus ion pairing. Phys. Chem. Chem. Phys. 10, 4793-4801 (2008).

82. Hanifpour, F., Sveinbjörnsson, A., Canales, C. P., Skúlason, E. \& Flosadóttir, H. D. Preparation of Nafion membranes for reproducible ammonia quantification in nitrogen reduction reaction experiments. Angew. Chem. Int. Ed. 59, 22938-22942 (2020).

83. Bastian, R., Weberling, R. \& Palilla, F. Ultraviolet spectrophotometric determination of nitrate: application to analysis of alkaline carbonates. Anal. Chem. 29, 1795-1797 (1957).

84. Hodgetts, R. Y. et al. Refining universal procedures for ammonium quantification via rapid ${ }^{1} \mathrm{H}$ NMR analysis for dinitrogen reduction studies. ACS Energy Lett. 5, 736-741 (2020).

85. Zhou, K. et al. Characterization and properties of $\mathrm{Zn} / \mathrm{Co}$ zeolitic imidazolate frameworks vs. ZIF-8 and ZIF-67. J. Mater. Chem. A 5, 952-957 (2017).

86. Dieckhöfer, S. et al. Probing the local reaction environment during high turnover carbon dioxide reduction with Ag-based gas diffusion electrodes. Chem. Eur. J. 27, 5906-5912 (2021)

87. Monteiro, M. C. O. et al. Probing the local activity of $\mathrm{CO}_{2}$ reduction on gold gas diffusion electrodes: effect of the catalyst loading and $\mathrm{CO}_{2}$ pressure. Chem. Sci. 12, 15682-15690 (2021). 


\section{Acknowledgements}

This project has received funding from the European Research Council (ERC) under the European Union's Horizon 2020 research and innovation programme (grant agreement CasCat [833408]) and in the framework of the Marie Skłodowska-Curie MSCA-ITN "Implantsens" [813006] as well as from the Deutsche Forschungsgemeinschaft (DFG, German Research Foundation) under Germany's Excellence Strategy-EXC 2033390677874-RESOLV and the "Center for Solvation Science ZEMOS" funded by the German Federal Ministry of Education and Research BMBF and by the Ministry of Culture and Research of Nord Rhine-Westphalia is acknowledged.

\section{Author contributions}

W.S. supervised this project. W.S. and W.H. conceived the project. W.H conducted the experiments. J.Z. performed the TEM measurements. S.D. performed the XPS and SECM measurements. S.V. performed the SEM and EDS measurements. W.H. and A.C.B. performed the Raman measurements. J.R.C.J. and A.L. performed the ${ }^{1} \mathrm{H}$ NMR measurements. S.S. carried out the XRD measurements. All authors contributed to the data analysis. W.S. and W.H. wrote the paper.

\section{Funding}

Open Access funding enabled and organized by Projekt DEAL.

\section{Competing interests}

The authors declare no competing interests.

\section{Additional information}

Supplementary information The online version contains supplementary material available at https://doi.org/10.1038/s41467-022-28728-4.
Correspondence and requests for materials should be addressed to Wolfgang Schuhmann.

Peer review information Nature Communications thanks Hoang-Long Du, Seung Woo Lee, Sergi Garcia-Segura, Zhong-Qun Tian and the other anonymous reviewer(s) for their contribution to the peer review of this work.

Reprints and permission information is available at http://www.nature.com/reprints

Publisher's note Springer Nature remains neutral with regard to jurisdictional claims in published maps and institutional affiliations.

\begin{abstract}
cc (i) Open Access This article is licensed under a Creative Commons Attribution 4.0 International License, which permits use, sharing, adaptation, distribution and reproduction in any medium or format, as long as you give appropriate credit to the original author(s) and the source, provide a link to the Creative Commons license, and indicate if changes were made. The images or other third party material in this article are included in the article's Creative Commons license, unless indicated otherwise in a credit line to the material. If material is not included in the article's Creative Commons license and your intended use is not permitted by statutory regulation or exceeds the permitted use, you will need to obtain permission directly from the copyright holder. To view a copy of this license, visit http://creativecommons.org/ licenses/by/4.0/.
\end{abstract}

(C) The Author(s) 2022 